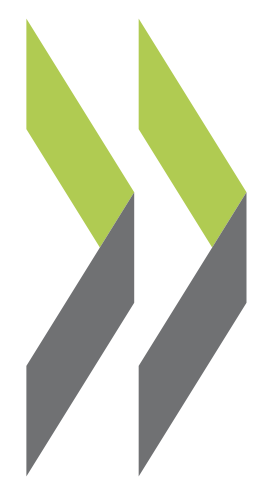

OECD Economics Department Working Papers No. 1096

\title{
Environmental Policies
}

and Productivity Growth: A

Critical Review of Empirical

Tomasz Koźluk,

Vera Zipperer Findings 
Organisation de Coopération et de Développement Économiques

Organisation for Economic Co-operation and Development

19-Nov-2013

ECONOMICS DEPARTMENT

English text only

ENVIRONMENTAL POLICIES AND PRODUCTIVITY GROWTH - A CRITICAL REVIEW OF EMPIRICAL FINDINGS

ECONOMICS DEPARTMENT WORKING PAPERS No. 1096

By Tomasz Koźluk and Vera Zipperer

All Economics Department Working Papers are available through OECD's Internet website at www.oecd.org/eco/Workingpapers

JT03348802

Complete document available on OLIS in its original format

This document and any map included herein are without prejudice to the status of or sovereignty over any territory, to the delimitation of international frontiers and boundaries and to the name of any territory, city or area. 


\section{ABSTRACT/RÉSUMÉ}

\section{Environmental policies and productivity growth - a critical review of empirical findings}

The economic effects of environmental policies are of central interest to policymakers. The traditional approach sees environmental policies as a burden on economic activity, at least in the short to medium term, as they raise costs without increasing output and restrict the set of production technologies and outputs. In contrast, the Porter Hypothesis claims that well-designed environmental policies can provide a 'free lunch' - encouraging innovation, bringing about gains in profitability and productivity that can outweigh the costs of the policy. This paper reviews the empirical evidence on the link between environmental policy stringency and productivity growth, and the various channels through which such effects can take place. The results are ambiguous, in particular as many of the studies are fragile and context-specific, impeding the generalisation of conclusions. Practical problems related to data, measurement and estimation strategies are discussed, leading to suggestions how they can be addressed in future research. These include: improving the measurement of environmental policy stringency; investigating into effects of different types of instruments and details of instrument design; exploiting cross-country variation; and the complementary use of different levels of aggregation.

JEL classification codes: D24; Q50; Q55; Q58; O47; O31.

Keywords: Environmental policy, Porter Hypothesis, Productivity, Innovation.

\section{Politiques environnementales et croissance de la productivité - un examen critique des résultats empiriques}

Les effets économiques des politiques environnementales revêtent un intérêt crucial pour les responsables de l'action publique. Suivant l'approche classique, les politiques environnementales sont considérées comme un fardeau pour l'activité économique, au moins dans une perspective de court à moyen terme, étant donné qu'elles entraînent une hausse des coûts sans pour autant faire augmenter la production et qu'elles limitent l'éventail des technologies de production et des produits. À l'inverse, suivant l'hypothèse de Porter, des politiques environnementales judicieusement conçues peuvent procurer des avantages sans contrepartie, en encourageant l'innovation et en débouchant sur des gains de rentabilité et de productivité qui peuvent l'emporter sur les coûts des politiques considérées. Nous examinons dans ce document de travail les données empiriques relatives à la relation existant entre la rigueur des politiques environnementales et la croissance de la productivité, ainsi que les différents canaux via lesquels les effets considérés peuvent se produire. Les résultats de cet examen sont ambigus, notamment dans la mesure où de nombreuses études sont fragiles et spécifiquement liées à un contexte donné, ce qui ne permet pas d'en généraliser les conclusions. Des problèmes pratiques liés aux données ainsi qu'aux stratégies de mesure et d'estimation sont examinés, et des propositions sont formulées en vue d'y remédier dans le cadre de futurs travaux de recherche. Il est notamment suggéré d'améliorer la mesure de la rigueur des politiques environnementales, d'analyser les effets des différents types d'instruments et d'examiner en détail leur conception, d'exploiter les variations observées entre pays, et d'utiliser de manière complémentaire différents niveaux d'agrégation.

Classification JEL : D24; Q50; Q55; Q58; O47; O31

Mots-clés : politique environnementale, hypothèse de Porter, productivité, innovation

(c) OECD (2013)

You can copy, download or print OECD content for your own use, and you can include excerpts from OECD publications, databases and multimedia products in your own documents, presentations, blogs, websites and teaching materials, provided that suitable acknowledgment of OECD as source and copyright owner is given. All requests for commercial use and translation rights should be submitted to rights@oecd.org. 


\section{TABLE OF CONTENTS}

\section{ENVIRONMENTAL POLICIES AND PRODUCTIVITY GROWTH - A CRITICAL REVIEW OF

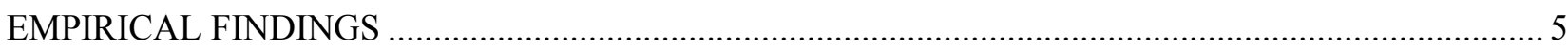

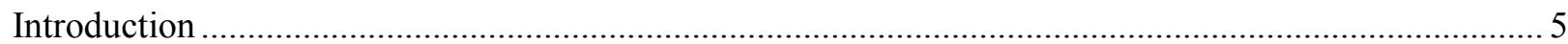

Background on the channels through which environmental policies may affect economic outcomes ....... 6

The conventional argument - diverting resources from productive allocations ..................................... 6

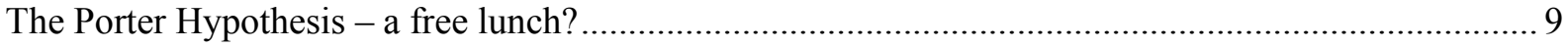

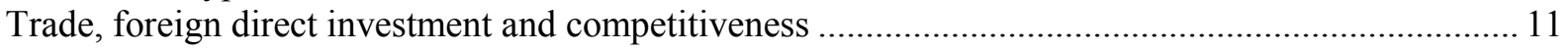

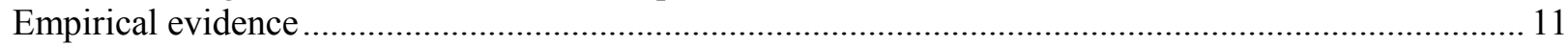

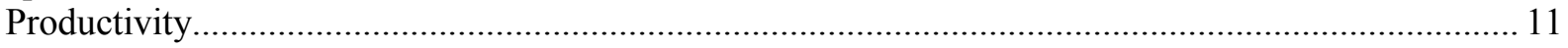

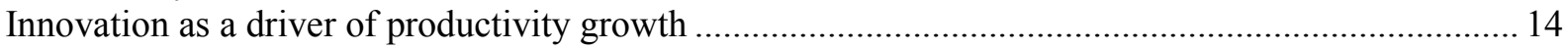

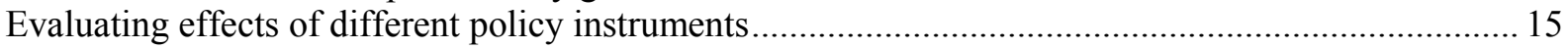

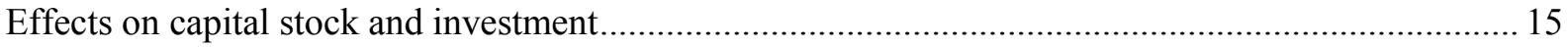

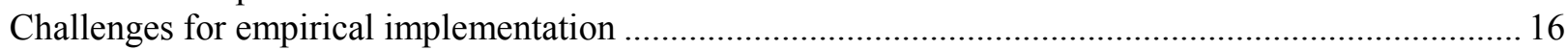

Measuring environmental policies - various approaches to the explanatory variable........................... 16

Time horizon matters but longer-term effects are difficult to capture................................................ 19

Studies at different levels of aggregation may yield complementary insight .................................... 20

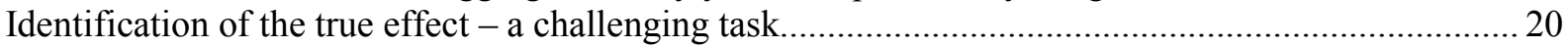

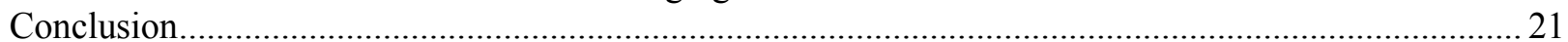

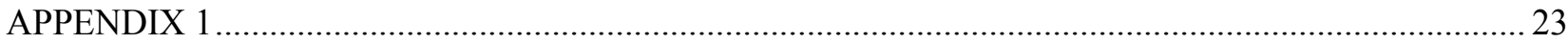

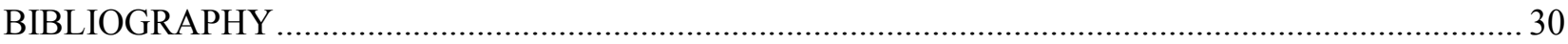

\section{Tables}

A1. Overview empirical studies

\section{Boxes}

1. Effects of environmental policies on measured MFP growth .......................................................... 8

2. Measuring productivity to account for environmental services .................................................... 9

3. Various versions of the Porter Hypothesis and some of the theoretical underpinnings ......................... 10

4. Abatement expenditures as proxy for stringency of environmental regulation.................................. 18 
ECO/WKP(2013)88 
ECO/WKP(2013)88

\title{
ENVIRONMENTAL POLICIES AND PRODUCTIVITY GROWTH - A CRITICAL REVIEW OF EMPIRICAL FINDINGS
}

\author{
by \\ Tomasz Koźluk and Vera Zipperer ${ }^{1}$
}

\section{Introduction}

1. The principal goal of environmental policies is to improve environmental outcomes, driven by the pursuit of objectives of broader wellbeing and ensuring sustainable growth. Environmental policies aim at achieving their objective by increasing the opportunity costs of pollution and environmental damage, curbing polluting behaviour, supporting investment and inducing innovation in less environmentally harmful technologies and so forth. However, they are likely to affect purely economic outcomes as well, particularly in the shorter term; these effects are of interest to policy makers when choosing to take action to improve environmental performance and selecting the relevant policy instruments.

2. A priori, the direction of the effect of environmental policies on macroeconomic variables such as GDP, productivity, innovation, employment, investment or trade, is far from clear. Traditionally, more stringent environmental policies have often been viewed as burdensome to economic performance - for instance by posing additional costs on producers without increasing output levels. Hence, they were considered detrimental to the profitability of the firm, productivity growth and GDP. For example, a number of studies attempted to attribute a significant part of the 1970s productivity slowdown in the United States to the increasing role of environmental policies (see Christainsen and Haveman, 1981, for a review). On the other hand, in the early 1990s, Michael Porter suggested that well-designed environmental policies might actually enhance productivity and increase innovation, yielding direct economic benefits next to the environmental benefits (Porter, 1991; Porter and van der Linde, 1995).

3. Empirical evidence on the effects of environmental policies on economic variables is rather weak. Many studies have been undertaken in the context of international trade, but empirical evidence on the effect on productivity is often context-specific and inconclusive. Early studies which were undertaken with the focus of explaining the contribution of environmental policy to the 1970s productivity slowdown in the United States, indeed found a negative effect on productivity growth, but more recent studies of the same phenomenon show either no effect at all or even a positive effect on productivity.

4. Several aspects of environmental policies matter for economic outcomes - in particular their stringency, flexibility and predictability. The objective of this paper is to review the existing empirical literature on the link between the stringency and flexibility of environmental policies on the one side, and

1. The authors are members of the Economics Department of the OECD. They would like to thank Jean-Luc Schneider, Giuseppe Nicoletti, Shardul Agrawala, Silvia Albrizio, Ivan Haščič and Jehan Sauvage, for their useful comments and suggestions. Special thanks go to Diane Scott for editorial support. The views expressed in this paper are those of the authors and do not necessarily represent those of the OECD or its member countries. 
productivity and innovation, on the other. The paper also gives an overview of the empirical evidence on environmental policies' effects on the capital stock, investment, and trade flows. The guiding questions of this analysis are: To which degree empirical findings can and do differ at the firm/industry/macro levels? Does the choice between market-based and command-and-control instruments matter for the effects of environmental policies on economic outcomes? If so, how?

5. The first section discusses the background intuition for the economic effects of environmental policies, the nature of the expected effects and potential channels through which they may work. This is followed by a section reviewing the results of different empirical studies. Next, challenges for empirical analysis are discussed, including an overview of the different measures of environmental policies used in the literature. The paper concludes with a summary of the main outstanding issues regarding investigation of such effects and provides some insights for future research.

\section{Background on the channels through which environmental policies may affect economic outcomes}

6. In a sense, the natural environment is an input into practically all economic activities. Environmental policies that guarantee the sustainable use of environmental assets can be seen as ensuring a certain level of productivity growth over the long term. While this is clearly not the only motivation for environmental policies, a counterfactual, disruptive development would mean lower productivity growth at some point, though potentially at the benefit of higher temporary growth in the shorter term.

7. Leaving the sustainability argument aside, long-term effects of an increase in the stringency of environmental policies on productivity growth, if present, are likely to hinge on the nature of the policy tool in question. Fairly static or one-off policy changes are likely to permanently affect productivity levels, but only temporarily affect productivity growth rates. Long-term changes in productivity growth could only occur if, for instance, environmental policies provide permanent incentives to innovate more, rather than just redirect innovation. This could be the case for more dynamic types of policies, increasing in stringency, such as emission caps, increasing environmental tax rates or performance standards with preannounced paths or if environmental policies increase competitive pressures. In the absence of more dynamic incentives, there are still various views on the direction and magnitude of short-term and mediumterm effects, as discussed later in this section. While much of the short to medium term discussion applies primarily to traditionally measured MFP growth, many of the arguments can also be made in the context of productivity measures that are adjusted for environmental inputs.

\section{The conventional argument - diverting resources from productive allocations}

8. Traditional views of environmental policies tend to see them as a cost or burden to economic activity, at least in the short to medium term. Leaving aside the long-term sustainability argument, compliance with environmental policies generally forces firms to devote some part of inputs to pollution prevention and abatement, which are not traditionally considered as value added, or to curb production (Jaffe et al. 1995, Ambec et al., 2013). The effects can be both direct - with firms' costs rising directly due to pollution abatement - and indirect, such as through increases in input prices in the industries affected by regulation (Barbera and McConnell, 1990).

9. More specifically, policies such as environmental taxes, tradable emission permits, or water and wastewater treatment charges impose an additional production-related cost for something that would be free otherwise, hence can induce firms to devote resources to reduce costly output. A similar argument can be developed for performance standards. Technology-based standards and restrictions or bans on certain substances can limit the range of production technologies available and otherwise profitable production output. In principle, if productivity could be increased by curbing environmental externalities, firms would 
have done so already, even in the absence of environmental policy. Hence the effect of environmental policies on productivity should be negative or, at best, neutral.

10. The effects of environmental policies on productivity might, however, be more complex as indirect effects work through a variety of channels. In the short-term, environmental policies may actually improve productivity in some specific activities - for instance industries using water as an input may benefit from the fact that water becomes cleaner, via reduced inputs devoted to water purification (Jaffe et al. 1995). Similarly, workers may become more productive if the adverse effects of air pollution on their health are curbed (Ostro, 1983 or more recently Graff Zivin and Neidel, 2012).

11. Indirect effects may come in the form of effects on the survival rate of firms. If, by imposing additional costs, environmental protection eliminates less efficient firms from the market, aggregate productivity is likely to rise. At the same time, additional (entry) costs, or vintage differentiated regulations can discourage entry and exit, reducing competition in the market, shielding potentially inefficient incumbents and obsolete capital stock, thereby leading to lower productivity levels and growth (Mohr and Saha, 2008; OECD, 2006; Heyes, 2013). Some further empirical evidence suggests that the plant birth rate is negatively influenced by environmental regulations (Gray, 1997).

12. Finally, environmental policies may also foster the creation of industries that would otherwise not exist or not benefit from economies of scale. The effects on productivity, while unlikely to be large on aggregate, are complex and uncertain a priori. For example, regulations that imply certain monitoring requirements may directly decrease the productivity of the concerned sector but may also boost both monitoring services and the production of relevant equipment - including by providing a first-mover advantage, if other countries eventually adopt similar laws. Municipal waste and wastewater treatment laws can induce new demand for such services and foster the growth of companies providing dedicated services. To the extent that such environmental policies involve public subsidies, aggregate effects need to take into account these funds are taxed away from productive activities. Empirically, industry-level effects will also depend on the level of aggregation used. Finally, the aggregate effects can be further complicated by international spill-overs and trade (OECD, 2013).

13. The overall rather negative perception of the effects of environmental policies on productivity growth stems partly from the nature of traditionally-measured MFP growth, which does not take into account environmental effects. In a simplified setting, it can be shown that environmental policies will negatively affect traditionally-measured MFP by definition (Box 1), even when they have no effect on broader productivity. Such ideas have led to various attempts at calculating adjusted MFP, or so-called "green" MFP, (see for instance Repetto et al., 1997; or Brandt et al., 2013) which would take into account the fact that pollution, or more broadly environmental services, can be seen as either an omitted output (side-product) or an omitted input. This concept lies also behind the Data Envelopment Analyses (DEA) on macro-level studies discussed in the section below (Box 2). 


\section{Box 1. Effects of environmental policies on measured MFP growth}

Environmentally adjusted measures of productivity growth are not aimed at answering the question about productivity effects of environmental policies per se. These productivity measures are rather developed to improve the measurement of productivity in the first place and can then be used to conduct analyses of the impact of environmental policies. Even assuming away any effects of environmental policies on actual MFP growth, traditional measures of MFP growth are likely to show changes due to the omission of environmental services in the production function. The intuition behind this can be demonstrated in a simple Cobb-Douglas production function with constant returns to scale and three inputs, capital (K), labour (L) and environment $(\mathrm{E}):^{1}$

$$
Y=A * K^{\alpha} L^{\beta} E^{1-\alpha-\beta}
$$

taking logarithms and differentiating with respect to time:

$$
\hat{A}=\hat{Y}-\alpha \widehat{K}-\beta \widehat{L}-(1-\alpha-\beta) \hat{E}
$$

where $\hat{X}$ refers to the growth rate of $X($ i.e. $d \ln X / d t$ ).

The Solow residual, is the actual or "environmentally adjusted" MFP growth, in the sense that it captures the difference between the increase in outputs and the increase in capital, labour and environmental inputs used to produce them. At the same time, if the role of environmental inputs is ignored in the basic production function:

$$
Y=B * K^{a} L^{1-a}
$$

the "measured" growth in MFP is equal to

$$
\widehat{B}=\hat{Y}-a \widehat{K}-(1-a) \hat{L}
$$

Assuming that the relative cost shares of labour and capital are not affected by the choice of measurement approach i.e. $\frac{a}{1-a}=\frac{\alpha}{\beta}$, equation (2) can be substituted into (4), which after rearranging gives:

$$
\widehat{B}=\hat{A}+(1-\alpha-\beta)\left[\widehat{E}-\left(\frac{1}{\alpha+\beta}\right)(\alpha \widehat{L}+\beta \widehat{K})\right]
$$

In which case, "measured" MFP growth $(\hat{B})$ is equal to "actual" MFP growth $(\hat{A})$ plus a bias. As the share of environmental services gets close to zero, this bias tends to disappear as $(\alpha+\beta)$ approaches 1 .

Assuming a new or a more strict environmental policy affects the (implicit or explicit) price of environmental inputs without affecting the prices of labour or capital, it will reduce the use of environmental inputs $(\widehat{E} \downarrow)$ and increase the use of labour $(\widehat{L} \uparrow)$ and/or capital $(\widehat{K} \uparrow)$. This means the bias will go down in levels. In a more complicated setting this could affect cost shares, but for simplicity this effect is ignored here.

If actual MFP growth $(\hat{A})$ is unaffected (as assumed initially), the lower bias implies that the growth of measured MFP $(\hat{B})$ will inevitably decrease. The intuition behind this measurement phenomenon can be found in Repetto et al. (1997): if the environmental policy change results in the substitution of part of a previously unobserved input ( $E$, which in this case is treated as part of the residual, B) with an observed input ( $K$ or $L$, for instance through the installation of pollution abatement equipment or hiring of monitoring personnel), leading to lower observed productivity. As the bias depends on the environmental policy regime in place, it might change with a change in environmental policy. One-shot policies and long-term incentive-based policies may have different effects on the over-time prevalence of such a change in the bias.

1. Environmental inputs can include any type of environmental services, such as natural resources, sink functions for pollution or land use. 


\section{Box 2. Measuring productivity to account for environmental services}

Environmental services, such as the use of natural inputs and sink services provided by the environment are ignored in traditional measures of productivity. In response, an increasing number of studies attempt to incorporate some of these services. Two methodologies dominate the literature - a distance function and an adjusted growth accounting framework.

In the distance function framework (including stochastic frontier analysis, StoFA), quantity data on inputs, traditional outputs and "bad" outputs are used to determine the technological production frontier, describing all possible efficient input/output combinations. For each possible input-output combination, the distance function then measures the possible efficiency gain of moving from an inefficient point on to the frontier. Studies that evaluate the effects of environmental regulation on productivity often model three scenarios by varying the assumption about the bad output: free disposability of bad outputs; a constant level of bad outputs while good outputs increase; and, a reduction of bad outputs at the same time as good output increases.

The second approach, based on a growth accounting framework, adjusts traditional productivity growth by the weighted difference of bad output and input growth. This requires assumptions on explicit shadow prices of pollutants (for an application see Brandt et al., 2013).

In practical applications, a key problem may be linked to the choice of environmental "bads" and their implicit weights, which depend on the underlying shadow prices. Studies tend to differ vastly in this respect, hindering comparability and generality of conclusions. Among bad output measures used are CO2 emissions (Wu and Wang, 2008), a combination of air and water pollutants (Yoruk and Zaim, 2005), air, water and toxic pollutant releases (Boyd and McClelland, 1999). Inevitably, such adjustments need to limit the bad outputs to a handful of environmental issues, meaning they may also hide an increase in other, non-measured environmental bads. Shadow prices of pollutants are rarely available and need to be estimated separately or proxied with observed prices, for example resulting from policies such as environmental taxes. Both approaches are fragile to the underlying assumptions. In the distance function framework Data Envelopment Analysis (DEA) allows calculating implicit shadow prices of pollutants, which are the basis for the productivity adjustment. As most of the studies do not attempt to calculate these prices, it is often not possible to assess whether they take reasonable values.

Source: Brandt et al. (2013).

\section{The Porter Hypothesis - a free lunch?}

14. If policies actually increase innovation they can enhance productivity growth. The general idea behind induced innovation goes back to Hicks (1932), and hinges upon the notion that increasing a factor's cost should spur innovation to economise on the use of this factor. ${ }^{2}$ In the 1990s, Michael Porter argued that indirect effects of well-designed environmental regulatory instruments might induce firms to innovate, which in turn might increase productivity and hence profitability - potentially outweighing the increase in abatement costs (Box 3). In this vein, environmental regulation which would set dynamic, long-lasting incentives to innovate more could increase both the level and the growth rate of productivity. These indirect effects might come through changes in the composition of inputs or through changes in the whole production process as the new regulation might shift the production function through stimulating the invention and adoption of new technologies. A priori, it is however unclear whether these indirect effects are negative or positive, or whether they are large enough to outweigh the drag of the direct effect. As Barbera and McConnell (1990) point out, more traditional inputs such as labour and capital might be needed as complements to the abatement capital and hence lead to a negative indirect effect. On the other

2. Hicks (1932), p. 124: “A change in the relative prices of the factors of production is itself a spur to invention, and to invention of a particular kind - directed to economising the use of a factor that has become relatively expensive." 
hand, old capital might be replaced with new investment, thereby increasing efficiency and leading to a positive direct effect.

\section{Box 3. Various versions of the Porter Hypothesis and some of the theoretical underpinnings}

In the early 1990's, the debate around the economic impacts of environmental regulation gained new momentum through an article written by M. E. Porter. He claimed that properly designed environmental regulation can trigger innovation which in turn can decrease, and even offset the costs of pollution abatement and enhance competitiveness (Porter, 1991; Porter and van der Linde, 1995). Initially, the Porter Hypothesis was suggested without any theoretical explanation of the factors at work or any comprehensive empirical evidence aside a few case studies which were collected by the authors.

The theoretical explanations for the possible existence of a Porter effect were only developed at a later stage. Generally speaking, the Porter Hypothesis assumes that there are profit opportunities for firms which are not fully used until the firms are pushed to do so by the implementation of a new environmental policy. A comprehensive overview of the development of the different theoretical arguments to provide a foundation for the Porter Hypothesis can be found it Ambec et al. (2013) and Wagner (2003). Behavioural arguments are based on the idea that managers may be risk averse, myopic or rationally bounded and hence may not be able to realise all profitable investment opportunities. Environmental regulation might then require certain investments which turn out to be profitable. Another approach hinges on the presence of market failures, such as imperfect competition (due to first-mover advantage or barriers to entry), asymmetric information (where 'green' products are not correctly valued by consumers), R\&D spill-over effects (as innovation has a public good character and leads to underinvestment), and organisational failure (where managers are able to lie about the true abatement costs in order to secure extra personal profits).

In order to find feasible empirical testing approaches, the Porter Hypothesis was divided into different subaspects which are nowadays known as the weak, strong and narrow version of the Porter Hypothesis (Jaffe and Palmer, 1997, were the first ones to differentiate the various aspects):

- The weak version of the Porter Hypothesis implies that environmental regulation will lead to an increase in environmental innovation. As Jaffe and Palmer (1997) describe, the firms subject to the new environmental regulation face an additional environmental constraint next to their financial ones. As firms are assumed to maximise profits, they will search for the most cost effective way to comply with the new regulation. The Porter Hypothesis suggests that firms will do so by innovating to reduce compliance costs, but does not necessarily imply more innovation in total.

- The strong version of the Porter Hypothesis claims that the cost savings from the improved production processes are sufficiently large to increase competitiveness. It rejects the assumption of perfect markets with profit maximizing firms and assumes instead that firms are not operating fully efficiently by leaving some profit opportunities unused. Environmental policies might hence induce the firm to rethink their production process. This might lead to extra profits which can in some cases be even larger than the costs of compliance. Various versions of this hypothesis have been tested, including the effects on more innovation and on actual company performance.

- Jaffe and Palmer (1997) describe also the narrow version of the Porter Hypothesis - certain types of environmental regulation, those which are designed to target the outcome rather than the design of the production processes, are more likely to increase innovation and improve company performance. In practice, this has been approached by looking how the use of more flexible or market-based instruments affects environmental and total innovation respectively.

15. Porter's arguments have met significant scepticism, though they had an important influence in environmental economics. Critics generally focus on the free-lunch argument, that is, that if there were productive opportunities available, they would have already been exploited by the firm. It is also unclear why policy-makers would be better aware than firms of the existence of these win-win areas to firms. Defendants tend to make the argument that because of market failures (e.g. information asymmetries), 
firms may be unwilling or unable to take a certain risk or action with net expected gains (Porter and van der Linde, 1995). Notably, Porter's arguments tend to rely on "well-designed" regulation. This makes inference from empirical estimations increasingly difficult because it can often be argued that the insignificant or negative effects of a specific environmental regulation on productivity come from its poor design, not from a negative effect per se. ${ }^{3}$

\section{Trade, foreign direct investment and competitiveness}

16. A large literature directly links environmental policies to competitiveness and trade outcomes (see Ambec et al. 2013, Wagner, 2003, Jaffe et al. 1995, for reviews). This literature is closely linked to the theory of pollution havens - pollution-heavy firms and investment relocating to environmentally lax countries. On the other hand, a number of scholars emphasise the first-mover advantages and accompanying gains in the technological frontier. By exploiting and affecting competitive advantages, international trade can also mitigate potential adverse effects of environmental policies on productivity outcomes, meaning desired environmental outcomes can be achieved at lower economic cost. These perspectives are in principle compatible with Porter's ideas - specialisation and relocation may be an efficient response and does not preclude improvements in productivity, both at home and abroad. Productivity is a key driver of competitiveness, but given that competitiveness is driven by several other key aspects, in particular costs and location, and is a relative rather than an absolute concept (Krugman, 1994), a detailed review goes beyond the scope of this paper. ${ }^{4}$

17. Research in this area indicates that environmental policies are unlikely to be major determinants of a country's competitiveness, trade or FDI patterns (see Jaffe et al., 1995, Brännlund and Lundgren, 2009 , Ambec et al., 2013, for reviews). This is probably because environmental costs are generally a small fraction of total firms' costs, which would also suggest relatively small effects on productivity growth. Competitiveness effects may also depend on country characteristics such as the level of development and income, trade openness, industrial structure and environmental, labour and other endowments, making the comparison of results of studies across different countries and periods difficult. Notably, the competitiveness literature has usually concentrated on the stringency of policies, rarely attempting to discriminate between different types of environmental policy tools.

\section{Empirical evidence}

18. In this review empirical research on the economic effects of environmental policies is classified according to the macro-economic measure analysed and the level of aggregation of the study. Details of the cited studies regarding scope, methodology and results can be found in Table A1 in the Appendix.

\section{Productivity}

19. The majority of studies on the productivity effect of environmental policies are conducted at the firm- and industry-level, with only a few papers adopting a macroeconomic view. Common approaches include cost-function estimates, growth accounting and efficiency measures adjusted for environmental outputs (Box 2).

3. This often omitted point is also made by Romstad (1998).

4. An important point in this context is that many studies look at a fairly short-term perspective, where the link between productivity and competitiveness is not as evident. 


\section{Firm- and plant-level studies using traditional productivity measures}

20. Plant-level studies tend to compare productivity growth among regulated and non-regulated plants, with estimated effects being overall rather negative but not very robust. Effects of environmental regulation on MFP growth are found to be negative (Gollop and Roberts, 1983; Smith and Sims, 1985) or insignificant (Berman and Bui, 2001a, in this case on productivity levels). None of these studies are able to control for potentially different characteristics of the two groups of plants, or to make a convincing case for ignoring such differences, which is a flaw in these types of fixed-effect or difference-in-difference approaches. Studies that do attempt to control for plant-level characteristics, including self-selection of firms into counties with more lax environmental regulation, tend to find many of them as significant determinants of productivity (for example, Becker , 2011; in case of labour productivity).

21. Even within one industry (pulp and paper in this case) effects of environmental regulation on plant productivity can depend strongly on plant characteristics. Gray and Shadbegian (2003) show that integrated mills, subject to stricter environmental regulation due to the integrated pulping process, show a significant reduction of productivity due to increases in abatement costs, whereas productivity of nonintegrated mills does not show any substantial reduction. Similarly, Becker (2011) finds no effect of environmental regulation on labour productivity levels in a broad sample of plants. Reducing the sample to plants which experienced a statistically-significant change in compliance costs over the years (only one tenth of the sample), the study finds a negative effect of compliance costs on labour productivity.

22. At the same time, the effects of pollutant-specific regulations on productivity levels can be very different, depending on the pollutant. Greenstone et al. (2012) find a persistent negative effect of total environmental regulations, while ozone regulations and particulates emission regulations are estimated to have a negative effect on productivity levels, sulphur dioxide emission have no significant effect and carbon monoxide regulations even foster productivity. The paper does not discuss the reasons for such differences in outcomes, which may come from a number of areas, for instance be due to different prevention and abatement technologies readily available in case of each of the various pollutants.

23. Aside from methodological issues the conclusions from the bulk of studies suffer from the lack of generality. They evaluate very specific regulations, focus on firms in specific industries (electric power; brewing; pulp and paper; and manufacturing respectively) in different countries (US and Canada) or areas (costal California), different time periods and horizons. Only Greenstone et al.(2012) accounts for plant closure while Becker (2011) and, to a lesser extent Gray and Shadbegian (2003), explicitly control for some firm characteristics that may drive productivity. None of the studies attempts to control for spillovers across firms.

\section{Firm- and plant-level studies using alternative measures of productivity}

24. A number of more recent studies takes into account bad outputs in the production process - and hence in the calculation of productivity - with the help of data envelopment analysis or stochastic frontier analysis (DEA and StoFA respectively, Box 2). Interestingly, even in this case, the results are far from uniform. Negative effects on (adjusted) productivity are found by Broberg et al. (2012) for the heavily regulated Swedish pulp and paper industry, with no effect on the manufacturing sector. The specification for the pulp and paper industry however, seems highly questionable due to an overall poor fit. Fleishman et al. (2009) find a multitude of different effects of the presence (but no effects of stringency) of air pollutant regulations for US power plants - positive, insignificant and negative - depending on types of plants and

types of regulation. Positive effects of more stringent policies on adjusted technical efficiency are found in the Dutch horticulture sector (Van der Vlist et al., 2007) and companies under the EU ETS (Jaraite and Di Maria, 2012). Both studies examine fairly narrow definitions of stringency and do not investigate mediumto long term effects. Managi et al. (2005), who allow for time-varying effects, find negative short-term 
effects of regulation on productivity levels in US offshore oil and gas fields, which disappear over time, eventually becoming positive and outweighing the initial drag on productivity.

\section{Industry-level studies}

25. The empirical evidence produced by industry-level studies is even more ambiguous. Early studies tend to find a negative effect, while more recent ones suggest a positive link between environmental regulation and productivity. These older studies tend to suffer from serious identification problems. One of the more widely cited studies that attempts to explain the US productivity slowdown in the 1970s with environmental regulation finds strong significant results, which disappear upon the inclusion of controls or elimination of outliers (Gray, 1987). Other studies that find negative effects on productivity growth either are unable to control for industry characteristics (Barbera and McConnell, 1990) or do so, but remain questionable due to a small sample (Dufour et al. 1998).

26. As in the case of plant-level studies, the industry studies analyse rather specific cases - countries, a handful of very specific industries (5 in Barbera and McConnell, 1990; and Hamamoto, 2006), and specific environmental laws. While Gray (1987) and Yang et al. (2012) analyse a set of several hundred industries, in other cases the cross-section dimension is more limited. The somewhat longer time series available allows some studies to attempt to look at the time dimension of effects (Hamamoto, 2006; Lanoie et al., 2008). The results potentially reflect the bulky nature of up-front expenditures in reaction to changes of environmental laws - finding the negative contemporaneous effect outweighed by the subsequent positive effects of regulation on MFP growth (Lanoie et al., 2008). On the contrary, Hamamoto (2006) finds significant positive effects of command and control regulations in Japan - on R\&D spending and in a second step on productivity growth - which tend to decline over time.

27. Differentiating between pollution abatement fees and pollution abatement capital expenditures can allow for dealing with some of the simultaneity problems of the Pollution Abatement Costs and Expenditures (PACE, see Box 4) environmental proxies. Capital expenditures are found to have no effect while abatement fees are found to stimulate R\&D and higher productivity (Yang et al., 2012), though the link between this (environmentally) induced R\&D and MFP levels is found weaker than in terms of general R\&D spending.

28. Adjusting productivity for "bad" outputs in a DEA framework does change the overall mixed conclusions - Domazlicky and Weber (2004) find no evidence of a link between environmental regulation and adjusted productivity growth in the US chemical sector. The only cross-country study, Alpay et al. (2002), similarly find no effect on adjusted productivity growth on the US food manufacturing sector, but a positive one in Mexico.

\section{Macroeconomic studies}

29. Empirical evidence at the aggregate economy level is very limited, largely because of data and identification problems. The approach taken by all of the studies surveyed is to include bad outputs in a distance function framework and hence allow crediting the reduction of pollution. Evidence is fairly inconclusive - scenarios with constant bad outputs (as a result of environmental policies) find negative effects on adjusted MFP growth (Jeon and Sickles, 2004) or slightly positive effects in a different sample of countries (Wu and Wang, 2008).

30. Interestingly, even in cases where the ratification of the UNFCCC is used as a proxy for environmental policy stringency, the effects on adjusted MFP growth can be positive (Yörük and Zaim, 2005 ) or negative (Wu and Wang, 2008). Explanations may relate to different samples - Yörük and Zaim (2005) focusing on OECD economies, Wu and Wang (2008) on APEC economies - or differences in the 
set of bad outputs used to adjust MFP growth - Yörük and Zaim (2005) using an average of air and water pollutants, while $\mathrm{Wu}$ and Wang (2008) focus only on $\mathrm{CO}_{2}$. More generally, in both cases the protocol ratification dummy seems rather prone to capturing a large number of other effects - an issue that would require further investigation.

\section{Innovation as a driver of productivity growth}

31. Innovation is a central aspect of productivity growth and has been studied in the context of effects of environmental policy stringency. The 'weak' version of the Porter Hypothesis (Box 3) - more stringent environmental regulation will increase environmental innovation ${ }^{5}$ - is basically a variation of Hick's (1932) argument and is fairly well supported by empirical evidence. On the contrary, there seems to be little evidence of firms actually innovating more overall:

- In a facility level approach stringency of policy tends to have a fairly strong effect on the decision to engage in environmental R\&D (Johnstone and Labonne, 2006; Arimura et al., 2007; and Lanoie et al., 2011, Yang et al. 2012).

- On the industry level, Jaffe and Palmer (1997) and Hamamoto (2006) find a positive effect of more stringent regulations on total R\&D expenditures. However, Jaffe and Palmer (1997) test and fail to find any effect on actual patents. Essentially re-running the former study for environmental patents Brunnermeier and Cohen (2003) find a small but significantly positive effect. In a similar vein, Kneller and Manderson (2012), find that in the UK manufacturing industries there is a positive relation between the stringency of environmental regulation and environmental R\&D expenditure, but not total R\&D expenditure.

- On a macro, cross-country level, some weak evidence of tighter environmental regulation on environmental innovation has been documented (Lanjouw and Mody, 1996; Popp, 2006; De Vries and Withagen, 2005). ${ }^{6}$

32. None of these studies looks into spillover effects across firms and industries. Overall, the general tendency to find positive effects contrasts somewhat with the dimmer picture when looking at actual productivity outcomes, as in the preceding section. This may be linked to the inherent challenges of actually measuring innovation, where the usual proxies based either on inputs (R\&D spending) or outputs (patent counts) may only be weakly related to actual innovation and tend to focus on quantity rather than quality. A further possible explanation could be linked to a tendency of firms to increase R\&D budgets at the expense of general R\&D. Others could include the decreasing returns from the increased environmental innovation (as in Hamamoto, 2006 and Yang et al. 2012). Finally, some of the effects could result from flaws of using self-reporting measures, such as PACE as proxy for environmental policy stringency. Purely technically, the time dimension may play a role - an increase in R\&D capital or personnel, even if potentially increasing productivity in the future - can be expected to decrease measured productivity contemporaneously (Box 1). While there is little evidence of actual increases in R\&D budgets, structural changes in the R\&D direction may still imply lags in terms of productivity.

5. The terms "environmental" innovation and "environmental" R\&D, used commonly in the literature, are often defined fairly loosely. The approach taken in this review is to use them very broadly, in relation to innovative and R\&D activity that focuses on reducing (some) environment-related effects, such as pollution or use of natural resources.

6. In De Vries and Withagen (2005) two out of the three measures of environmental regulation do not have any significant effect on environmental innovation. Their preferred model, which uses an instrumental variable approach, shows a significant and rather large positive effect on the number of environmental patents, they fail to provide any details on the validity of the instrumental variable approach. 
ECO/WKP(2013)88

\section{Evaluating effects of different policy instruments}

33. More flexible environmental policy instruments are, under certain conditions, seen as achieving environmental goals in combination with superior economic outcomes due to their static and dynamic efficiency properties (see de Serres et al. 2011 for a review). Hence, the so-called "narrow" version interpretation of the Porter Hypothesis, stipulates that more flexible, market-based instruments will stimulate higher innovation than less flexible command and control policies (Box 3). Few studies allow for the testing of such a hypothesis, given that most focus on either a single policy change or on a measure of policies that does not allow distinction between different instruments.

34. As a result, only a handful of studies look at whether more flexible instruments cause more environmental innovation. Both Johnstone and Labonne (2006) and Lanoie et al., (2011) find marginal and rather fragile evidence for performance standards yielding more innovation, in the latter case with respect to the less flexible technological standards. At the same time, they find no effect of taxes with respect to other instruments. Johnstone et al. (2010b) find some evidence of perceived flexibility of environmental policies increasing patenting behaviour, albeit need to recur factor analysis to extract the variation in crosscountry perceived flexibility, which tends to be highly correlated with stringency. Arimura et al. (2007) do not find any different effects of voluntary approaches relative to command and control measures. Possible explanations for the above findings are the difficulty of assessing the actual flexibility of an instrument and omitted variables. The fact that different types of policy instruments are effective for stimulating innovation activity in different sectors might also lead to contradicting results of studies. In the renewable energy sector for example, broad policies, such as tradable energy certificates are more effective in more mature technologies, while more targeted subsidies, such as feed-in tariffs are more effective in case of more costly technologies (Johnstone et al., 2010a).

35. The only study that looks at overall innovation effects, Hamamoto (2006) claims that in Japan in the 1960s and 1970s command and control policies did trigger higher overall R\&D activity but that a $\mathrm{SO}_{\mathrm{x}}$ charge, which was introduced later, did not.

\section{Effects on capital stock and investment}

36. As environmental regulation often induces investment into pollution abatement capital (shown also empirically e.g. by Gollop and Roberts, 1983, Berman and Bui, 2001a), theory suggests that this "abatement investment" might crowd out 'non-environmental investment' into productive capital, potentially putting future productivity at risk. The empirical evidence on a possible crowding-out effect of investment is mixed. As Jaffe et al. (1995) conclude in their literature survey, there is no clear empirical evidence for a decrease in total investment due to necessary pollution abatement investment. Some evidence of crowding out has been observed (Rose, 1983; Gray and Shadbegian, 1998, 2003), while other studies found no effects (Kneller and Manderson, 2012). Still, the bulk of studies include at most a one year lag, failing to account for the fact that productivity-relevant effects on capital investment are likely to be of a longer-term nature.

37. Stricter environmental policies can also bring forward the obsolescence of existing capital. On the other hand, they may decrease entry (and exit), lengthen the life of polluting capital and actually delay investment (Heyes, 2013). There are only very few studies that analyse the effect of environmental regulation on the age of capital stock. The "modernising effect" of the capital stock (Xepapades and de Zeeuw, 1999) might be triggered by a downsizing of the capital stock or by investment into new machines, as confirmed by Hamamoto (2006) who finds a decrease in the average age of the capital stock in Japanese manufacturing in response to more stringent policies. On the other hand Nelson et al (1993) find an increase in the age of capital stock, meaning a reduction in reinvestment in capital, in a sample of electric utilities in the United States. The different results may be linked to the market structure in the sectors 
examined and specific aspects of the environmental policies, in particular if vintage differentiated laws are adopted - as for instance in the case of the New Source Review of the US Clean Air Act.

\section{Challenges for empirical implementation}

38. Neither the choice of the set-up nor the identification strategy of empirical analyses of the economic effects of environmental policies is straightforward. The choice of the level of aggregation determines which effects can and cannot be captured in the analysis. The choice of variables and datasets are equally challenging, in particular with respect to the timing of effects. Analyses of the effect on innovation face the problem of measuring the latter through proxies. A clear, basic challenge confronting all studies is the measurement of the policy variable - that is finding a suitable, measurable variable for the stringency of environmental regulation.

\section{Measuring environmental policies - various approaches to the explanatory variable}

39. Estimating the effect of environmental policies often requires a proxy variable for the stringency of the regulation. In a comprehensive review of available measures, Brunel and Levinson (2013) list multidimensionality and simultaneity among the main issues to be solved in such measurement. In particular, multidimensionality represents the challenge to summarise - in a meaningful and comparable way - the potentially available information on stringency across different pollutants (with different short and long-term effects, local and national or global in nature); different environmental domains or media; and a multitude of instruments (often industry, pollutant, location and vintage specific) in the context of countries with very different industrial structures and geographical characteristics. Simultaneity can be seen as a general problem - affecting both the measurement of policies itself and the actual empirical applications of the policy stringency variable. The latter is discussed in the section on identification below, but the former problem affects a number of measures used in the literature - particularly those based on outcomes of policies, such as spending or emissions, rather than actual policy characteristics. In this case simultaneity arises from the fact that measured environmental policy stringency cannot distinguish the effect of actual environmental policy stringency from that of other contributors to the measured outcome, such as non-environmental regulations; market imperfections; levels of income, skills and technology; capital intensity and pollution levels. While various attempts at measuring environmental policy stringency have been used in the past, none addresses the above considerations in a satisfactory manner.

40. There are several dominant approaches to measuring environmental policies in the empirical literature (Table A1):

- One of the most popular is the use of survey-based firm or plant-level expenditures, which are interpreted as induced by environmental rules and hence intended to proxy for their stringency. The US Pollution Abatement Costs and Expenditures (PACE) and more generally environmental protection expenditures (Box 4) are widely used examples (Gray, 1987, Morgenstern et al., 2002; Gray and Shadbegian, 2003). This measure suffers from poor comparability across countries and time, problems of counterfactuals, or defining what part of expenditures are driven by environmental policies, the self-reporting nature of the surveys and sampling. Moreover, it may run into conceptual problems in the case of attempts to assess the Porter Hypothesis, where for instance expenditures on innovative, pollution reducing technologies could be considered on both the left and right hand side of the equation. Moreover, they are to some degree endogenous higher compliance costs may come from older plants and technologies, rather than stricter policies (Ambec et al, 2013).

- As an alternative, "shadow prices" of pollution are proposed (reviewed in more detail by Brunel and Levinson, 2013). These stem from the idea that environmental policies put a price on 
pollution, hence the more stringent the policies, the higher the price faced by polluters, affecting their optimisation decisions. The main appeal of this approach is the fact that it focuses on the estimated "cost" of pollution faced by the firm, regardless of the instrument mix in place, circumventing the problem of multidimensionality. However, among the main problems are simultaneity (estimated shadow prices are also affected by other factors) and strong reliance on estimation assumptions (for example, regarding the functional form of the cost or production functions).

- A number of studies have used environmental or related performance data as a measure of policy stringency. Examples include energy intensity (Cole and Elliot, 2003; Van Beers and Van den Bergh, 1997, Harris et al., 2003), state compliance with environmental standards (McConnell and Schwab, 1990), and pollutant emission intensity (Smarzynska and Wei, 2004). Brunel and Levinson (2013) themselves follow this approach, proposing a measure of actual pollution intensity relative to what could be expected given the country's industrial structure. While interesting, particularly in cross-country empirical applications such measures tend to suffer from simultaneity and possible reverse causality as these measures might be influenced by e.g. differences in factor prices, technology and industrial structure more than by environmental regulation.

- Perceptions of the stringency of laws and their enforcement, as compiled by the World Economic Forum (WEF), ${ }^{7}$ were used by Kalamova and Johnstone (2011) and Johnstone et al. (2010b). Similarly, Johnstone and Labonne (2006) and Lanoie et al. (2011), use survey based company level perceptions of the stringency of environmental regulations. ${ }^{8}$ While potentially reflecting what matters - that is the stringency perceived by those who are affected - such measures have several downsides: they are context-specific (e.g. depending on the business cycle), linked to respondents subjectivity, problematic in international and inter-temporal comparability, and prone to the state of the economy (cyclicality) and sampling bias (for example, reflecting only the 'incumbents' views).

- Some studies, in particular those based on difference-in-difference estimations, use a more eventbased approach, based on the event of introduction or significant change in a particular policy (Berman and Bui, 2001b; Van der Vlist et al., 2007; Curtis, 2012). While these approaches may better capture causal relationships in the case of very specific effects of individual policy changes, this will often be at the sacrifice of the generality of conclusions. Moreover, by measuring de jure aspects of environmental policies, they may omit implementation details and the enforcement of the environmental regulation.

- Others have experimented with broader policy proxies. Examples include the ratifications of international environmental treaties (counts, as in Smarzynska and Wei, 2004; or incidence, as in Yörük and Zaim, 2005 or $\mathrm{Wu}$ and Wang, 2008) or policy instruments in a given environmental

7. The WEF's "Executive Opinion Survey", conducted annually, asks respondents (business executives) a number of questions related to environmental policy design. The questions, coverage and sampling have varied across the years, but the most common questions were to assess the "stringency" (and "enforcement") of the overall environmental regulation in the country of operation, on a 1 to 7 scale. The survey was implemented by the WEF's partner institutes in over 150 economies. In most years, there were responses from between 8000 and 15000 firms (see WEF, 2013; for a description of the sampling strategy.) http://www3.weforum.org/docs/WEF_GlobalCompetitivenessReport 2012-13.pdf.

8. The 2003 survey data were collected for the manufacturing sector in seven OECD countries and include information on environmental R\&D expenditure, environmental and commercial performance and perceived stringency of environmental regulation. 
domain (Jaraité and Di Maria, 2012). These measures apply only to a specific industry or pollutant dimension, several other approaches have attempted to summarise information in a number of "representative" industry and pollutant dimensions to create a more general index of environmental policy stringency (Berman and Bui, 2001a; Fleishman et al., 2009). These may again suffer from a selective approach, possibly omitting crucial areas, and in an international context often from aggregation issues when quantifying and compiling the stringency across very different instruments, pollutants and industrial structures. They also focus on the de jure rather than the de facto stringency of environmental policies.

- The spectrum of other proxies used in empirical studies is wide, including congressional proenvironment voting records of state representatives (Gray, 1997) or environment-related inspection frequency (Alpay et al., 2002; Testa et al., 2011; Brunnermeier and Cohen, 2003).

\section{Box 4. Abatement expenditures as proxy for stringency of environmental regulation}

Firm and industry-level data on environmental protection expenditure, defined as expenditures on "purposeful activities aimed directly at the prevention, reduction and elimination of pollution or nuisances arising as a residual of production processes" (OECD, 2007), are collected since the 1970s by national authorities and the OECD. The most known example is the PACE - a plant-level survey that asks questions on pollution abatement capital expenditures and operating costs associated with compliance to local, state, and federal regulations and voluntary or market-driven pollution abatement activities. The PACE survey was conducted by the U.S. Census Bureau between 1973 and 1994 (annually, with the exception of 1987), and discontinued thereafter. The Environmental Protection Agency picked up the bill for a 1999 survey, which, however, had significant conceptual differences relative to the previous waves, complicating time-series analysis (Becker and Shadbegian, 2004). A new survey followed in 2005, and is for the moment the last one conducted. A similar, though not directly comparable concept governs the Joint OECD/Eurostat Questionnaire on Environmental Protection Expenditure and Revenues (EPER), which was commenced in the late 1990s for EU countries, and several other exercises across countries such as in Canada or Korea.

Empirical studies that use environmental pollution abatement costs as a measure of environmental policy stringency rely primarily on the assumption that higher environment-related expenditure is induced by more strict environmental policy. In practice this concept faces a number of drawbacks, some of which are emphasised in an international context. First of all, the data are often not easily comparable across countries and over time. Second, it is difficult to classify expenditures - for example distinguishing what share of costs of a change in technology is driven by environmental policies and what share by profits. This relates to the issue of counterfactuals, that is identifying an expenditure scenario without environmental policies. The self-reporting nature of the exercise may exacerbate such issues, as different firm (and country) characteristics may influence responses. In fact, Broberg et al (2012) claim that the pulp and paper industry generally categorises investments into closed-loop systems, which recycle and reuse wastewater, as environmental investment even though it is purely driven by profitability considerations. Over-reporting may also be a result of attempts by industries to gain a "green" image or to signal voluntary efforts in order to avoid hard policy intervention. On the other hand, Berman and Bui (2001a) claim that costs of abatement are often incompletely measured, such as for example a switch to another fuel where the extra cost of this switch is not reported. Arguments in both directions are also provided by Brunnermeier and Cohen (2003). Moreover, the share of such type of expenditures may also reflect regulations that are external to environmental policies - for example stricter safety regulations may improve safety (and hence lower the need for environmental pollution abatement). Finally, there is a sample selection issue: if environmental policies lead to changes in the industry structure, with firm entry and exit, this phenomena may not be easily captured with firm-level questionnaires.

Sources: Becker and Shadbegian (2004), OECD (2007).

41. Overall, the choice of the most appropriate variables is likely to depend on data availability and the nature of the exercise - for example the type of pollution in question or the type of cross section units. In the context of international analysis, the use of a composite index, summarising information across a number of the main dimensions of environmental policies seems rather underexploited. This may be a consequence of poor data availability, and potential risks related to the choice of areas and quantification 
and aggregation of gathered information. Nonetheless, this omission is striking given that similar attempts have taken place in areas of significant complexity and multidimensionality, such as Product Market Regulation or Employment Protection Legislation (Nicoletti et al., 2000).

\section{Time horizon matters but longer-term effects are difficult to capture}

42. The time dimension of the economic effects of environmental policy may depend on the specific policy design and its announcement. On the one hand impacts may precede the date of introduction of the policy - firms can decide to make investments or change technologies upon announcement or even in anticipation of a new environmental rule. This argument however, relies strongly on the assumption that the policy change is credible and announced well in advance, for firms to take early action. Such a situation can arise due to international obligations - which require policy action by a certain date (frequent case in the EU) or due to a general perception of tightening of environmental rules, or a stable commitment to environmental policies - for instance Johnstone et al. (2010b) find a significant role of environmental policy predictability in triggering investment into renewable energy innovation. This might reflect the more general argument that in the presence of higher uncertainty of future laws firms may delay investments and adoption of new technologies (Shadbegian and Gray, 2005). On the other hand, impacts may take time - if policies trigger higher R\&D investment, it may take years to actually bring about measurable improvements in technology and processes. In this vein, Jaffe and Palmer (1997) find a positive effect of pollution control expenditures on R\&D expenditure in the manufacturing sector in the US in 1975 - 1991, yet no significant effect on the number of successful patents.

43. By sheer nature, short-term and long-term effects may differ. If a new policy induces lump-sum investment, be it into capital (necessitated directly for pollution reduction or due to an accelerated scrapping rate as old "dirty" capital becomes obsolete), hiring of new personnel (to cope with environmental requirements or as a change of technology) or increased R\&D expenditure, short term inputs will increase without an equivalent increase in output. This would show up in curbed productivity growth. Thereafter, rebound effects or the benefits of new technologies may imply temporarily higher productivity growth - even assuming away the strong version of Porter's Hypothesis. While these effects may eventually fade out, with productivity growth returning back to trend, most empirical studies focusing on short-term or even contemporaneous effects will have a problem capturing the dynamics of such developments. Further complications may arise from the fact that less environmentally-efficient companies may go bankrupt as a result of regulation, while new companies may enter the market. Such effects are rarely taken into account in empirical research. Finally, trade and regulation avoidance may complicate the picture further, as for instance firms may tend to reallocate production and investment to plants subject to more lax environmental rules among US states (Gray and Shadbegian, 1998), or commence activity in States with less stringent legislation (Gray, 1997).

44. The focus on contemporaneous and short-term effects in empirical literature is driven by data availability and attempts to capture some longer-term effects have been fairly modest. Notable efforts include Managi et al. (2005) include up to eight years of the lagged policy variable in their analysis of productivity growth in the offshore oil and gas industry in the US. They find a negative contemporaneous effect. After the second year, the regulation's effect on productivity becomes positive. The accumulated effect outweighs the initial negative impact after the fourth year. The subsequent lags are also significantly positive. Lanoie et al. (2008) provide similar evidence for the Canadian manufacturing sector: the negative contemporaneous effect on productivity growth is outweighed by the accumulated effect after three years. Similarly, for the Taiwanese manufacturing sector Yang et al. (2012) find a small but significantly positive effect of the second year lag, but do not include further lags due to the short sample. Hamamoto (2006) tests different lag-structures in several models and shows that the specification of the six year lag fits better in terms of explained variability than for example a three-year lag structure. In a study of Swedish manufacturing industries, Broberg et al. (2012) do not find a significant longer-term effect. Only when 
looking explicitly at the pulp and paper industry, a significant negative effect appears with a two year lag. Greenstone et al (2012) investigate the manufacturing sector in the US and find a negative dynamic effect as well.

45. Much of the research discussed above takes a fairly static approach to environmental policies - one looking for a single, unique effect of a unique policy change. However, as discussed in de Serres et al. (2010), the nature of incentives provided by policies may be more dynamic. For instance, market-based instruments tend to provide more persistent incentives to innovate and to increase productivity than other policy instruments. These effects can be even stronger if policies have longer time horizons - for example when tax rates or caps on carbon emissions are (credibly) announced for years to come (such as in the case of the EU ETS), or when standards depending on best available technologies are to be revised periodically. Such characteristics of environmental policies are rarely straightforward to capture through standard measures of stringency and hence are usually ignored in empirical analysis.

\section{Studies at different levels of aggregation may yield complementary insight}

46. In the case of firm- or plant-level studies most standard data sets are fairly limited - they offer a short time series and often focus on firms in particular sectors and countries, hence limiting the generality of the investigation. Such datasets generally cover only incumbent firms over the sample period, leading to a disregard for entry and exit, which may reflect precisely the effects of environmental policies. In practice, very few studies actually attempt to adjust their estimates for entry and exit of firms using alternative data sources. Greenstone et al. (2012) show that the negative estimated effects of environmental policies on productivity are actually larger when adjusted for the fact that most inefficient firms drop out of the sample as a result of the environmental laws. For employment outcomes, Berman and Bui (2001b) find however no effect of taking account of dissuaded entry and induced exit. Finally, studies ignore network and spillover effects, such as tighter policies in a given sector spurring innovation and productivity growth in sectors that are not directly affected by the regulation (e.g. ICT, electronics, chemicals or pollution abatement equipment and services).

47. Industry-level studies potentially provide longer time-series and are more suitable for dealing with entry and exit, but still usually ignore network and spillover effects. The level of aggregation of industries may matter - some effects may be missed at higher levels of aggregation, while lower levels will suffer from lack of data. Similarly, industry-level analysis will also miss the costs of labour substitution or movement from one plant to another, when total industry employment remains stable (Morgenstern et al., 2002). Furthermore, many studies tend to focus on a subset of industries only (e.g. Barbera and McConnell, 1990; Hamamoto, 2006; Yang et al. 2012).

48. The macroeconomic level approach potentially deals with some of the above issues by capturing the overall effects on productivity. They also offer more policy instrument variation than present in a single sector and often longer time series. These advantages come at a cost - measurement and comparison of policies may be more cumbersome - requiring to summarise multidimensional information, as discussed before. Moreover, the identification of effects of policy changes becomes difficult, and requires controlling for a wide range of other variables.

\section{Identification of the true effect - a challenging task}

49. Environmental policies are rarely introduced in isolation, making it difficult to assess their individual effects. Environmental policies can interact with each other and are often accompanied by mitigating measures, designed to soften perceived adverse impacts; by promoting environmental action in other countries; or even by border tax adjustments (OECD, 2010). The simultaneous implementation of related measures makes it difficult to properly identify the initial effect and to attribute an observed 
economic outcome to the specific policy under consideration. Moreover, many measures are temporary and eventually reversed, which due to time lags in their implementation and effects poses a further challenge for the identification of actual effects.

50. The comparability across studies suffers from the fact that different types of policy instruments as such can have different economic effects. The stringency of an appropriately designed performance-based standard for example might rely on the best available technologies, and will hence increase as more environmentally efficient technologies develop. On the other hand, the effective stringency of a fixed pollution cap may decrease over time for the very same reason. This makes it difficult to compare studies analysing different policy approaches.

51. One additional complication for empirical analysis is the potential reverse causality, that is, the extent to which the stringency of environmental policies is driven by productivity growth, causing practical problems for estimation such as biased estimates (Gray, 1987). As economic growth can spur demand for environmental quality (environmental Kuznets curve), stricter environmental laws might be a response of policy makers to this increasing demand. Similarly, environmental policies create new rent opportunities and as such can incentivise lobbying for more stringent laws. In an attempt to deal with issues of this type Managi et al. (2005) use a Granger causality test to investigate if environmental stringency is affected by productivity growth in the offshore oil and gas industry, and cannot reject non-causality.

\section{Conclusion}

52. Empirical research on the productivity effects of environmental policies is largely inconclusive. Results are usually very context-specific and hence of little use for policy makers deciding on which tools to choose to tackle a particular environmental issue. The fairly broad support for the weak version of the Porter Hypothesis is not very surprising. However, the findings of an ambiguous effect of environmental policies on productivity, in line with the strong $\mathrm{PH}$, are rather unexpected, considering the earlier research aimed at explaining the US productivity slowdown with the tightening of environmental regulation.

53. Finding significant effects of environmental policy changes may be hard because environmental compliance costs are usually only a small share of total costs (Gray and Shadbegian, 2003). The size of the effects that are found in different studies reviewed is hardly comparable, mainly due to the crudeness of the environmental policy proxy variable.

54. Firm-level difference-in-difference studies are methodologically the most convincing approach. These studies allow clear identification of the economic effects of environmental policies, which helps to understand the forces at work on a microeconomic level. However, the very same argument implies that these studies suffer from lack of generality, as they give a very context-specific answer to a very specific question, making their results of little interest for policy makers. Most studies also have problems dealing with a selection bias, dynamics (short samples), sample selection (entry/exit) or network effects/spill-overs. Moreover, given the likely change in a single tool, they are also poorly suited to differentiate the effects of market-based and command-and-control policies. At the industry-level, generality is also dubious, and the bulk of older studies tend to suffer from the simultaneity problem. Spill-overs across industries are left unaccounted for. While in practice only DEA studies control for environmental outcomes, the use of environmentally adjusted productivity per se is asking a different question - no longer focusing on pure economic performance but implicitly weighting it against environmental performance (Box 1 and 2).

55. In terms of methodology, several general ideas for future research can be drawn:

- Firstly, adding an international dimension can increase the variation both across policies and across outcomes, providing a richer sample. This could possibly reduce the need for a longer time 
series. So far, studies predominantly tend to look at national effects of national policies. With respect to many of the studies, aside perhaps some of those conducted across US states, this additional degree of variation, both in policies and in outcomes, can allow for better identification of effects, hence easing some of the simultaneity issues. Such a comprehensive approach can also prove more suitable in comparing effects of market-based and command-and-control instruments, or other pertinent aspects of policy design, such as imposed administrative burdens, barriers to entry, exit and competition.

- Second, combining various levels of aggregation, such as macro, industry and firm-level, can yield complementary insights. Most studies look at one single level, while as discussed above, effects can differ significantly on each of the levels, due to considerations such as entry/exit, and spill-over and network effects, and international trade. Looking at the three levels can help reconcile results that seem to be conflicting.

- The utilisation of composite measures of environmental policies in cross-country comparisons can provide interesting insight on the burdens associated with command-and-control and more flexible policies. The use of such composite indexes is rather scarce so far. This can partly be explained by the prevailing interest in national level studies, where effects of policies might better be analysed using more direct measures, such as discrete changes in specific policies. In the context of international comparisons, where different countries tend to use a multitude of different tools (Botta, 2014), an effort to construct such composite index can however provide a basis to analyse effects of market-based versus command-an-control regulations in an international context. Practical challenges in constructing such composite indexes are surely also relevant, for example the complexity of multi-dimensional environmental policies and the data gathering process. Tackling these challenges, a composite index can provide policymakers more insight on the choice among different policy approaches available.

- More research is warranted on the extent to which the details of environmental policy design and implementation affect market entry and competition. Environmental policies aim at environmental outcomes and, as shown in this review, the evidence on the link between policy stringency and productivity growth is inconclusive. At the same time, there is significant evidence that competition is a key determinant of productivity outcomes. The details of environmental policy design, rarely empirically investigated, can have important implications on competition in the market, for instance by increasing the administrative barriers to entry, or by discriminating directly against new entrants. While this trade-off may be unavoidable, pursuing economic objectives requires it to be minimised. Looking into this problem needs the collection and analysis of information on the design of environmental policies in a notion similar to that behind more general regulation, as captured by the OECD's work on Product Market Regulation (Koźluk, 2014). 


\section{APPENDIX 1}

Table A1. Overview empirical studies

\begin{tabular}{|c|c|c|c|c|c|}
\hline Author and year & Dep. variable & Independent variable & Sample & Methodology & Result \\
\hline \multicolumn{6}{|c|}{ Productivity measures } \\
\hline $\begin{array}{l}\text { Gollop and } \\
\text { Roberts (1983) }\end{array}$ & $\triangle T F P$ & $\begin{array}{l}\text { Ratio of legal } \\
\text { emission target to } \\
\text { effective enforcement }\end{array}$ & $\begin{array}{l}\text { American electric } \\
\text { power industry, } \\
1973-1979(\mathrm{~F})\end{array}$ & $\begin{array}{l}\text { - compares estimated productivity } \\
\text { and growth contributions across } \\
\text { regulated and non-regulated } \\
\text { plants }\end{array}$ & $\begin{array}{l}\text { - productivity growth is reduced for restricted } \\
\text { plants, by } 0.5 \text { percentage points per year on } \\
\text { average } \\
\text { - evidence for increased costs due to sulphur } \\
\text { dioxide emission restriction }\end{array}$ \\
\hline $\begin{array}{l}\text { Smith and Sims } \\
\text { (1985) }\end{array}$ & $\triangle \mathrm{TFP}$ & $\begin{array}{l}\text { Payments for BOD } \\
\text { and SS emissions }\end{array}$ & $\begin{array}{l}\text { Canadian } \\
\text { brewing industry, } \\
1971-1980(\mathrm{~F})\end{array}$ & $\begin{array}{l}\text { - compare productivity growth of } \\
\text { regulated and non-regulated firms }\end{array}$ & $\begin{array}{l}\text { - negative impact of pollution charges on } \\
\text { productivity growth }\end{array}$ \\
\hline $\begin{array}{l}\text { Berman and Bui } \\
\text { (2001a) }\end{array}$ & TFP & $\begin{array}{l}\text { Count variable of } \\
\text { number of } \\
\text { regulations in place }\end{array}$ & $\begin{array}{l}\text { American oil } \\
\text { refineries (Los } \\
\text { Angeles basin), } \\
1977-1992(\mathrm{~F})\end{array}$ & $\begin{array}{l}\text { - fixed effect estimation } \\
\text { - compared regulated and non- } \\
\text { regulated refineries }\end{array}$ & $\begin{array}{l}\text { - positive, insignificant effect for regulated plants } \\
\text { costs due to regulation found }\end{array}$ \\
\hline $\begin{array}{l}\text { Gray and } \\
\text { Shadbegian } \\
\text { (2003) }\end{array}$ & TFP & PAOC & $\begin{array}{l}\text { American pulp } \\
\text { and paper mills, } \\
1979-1990(F)\end{array}$ & $\begin{array}{l}\text { - fixed effect and GMM estimation } \\
\text { of regression of TFP and PAOC } \\
\text { and directly of production function } \\
\text { which includes PAOC }\end{array}$ & $\begin{array}{l}\text { - negative effect on productivity levels is driven by } \\
\text { integrated mills; effect for non-integrated mills is } \\
\text { negligible }\end{array}$ \\
\hline $\begin{array}{l}\text { Greenstone et } \\
\text { al. (2012) }\end{array}$ & TFP & $\begin{array}{l}\text { Dummy variable of } \\
\text { attainment/nonattain } \\
\text { ment of air pollution } \\
\text { regulations }\end{array}$ & $\begin{array}{l}\text { American } \\
\text { manufacturing } \\
\text { sector, } 1972- \\
1993(\mathrm{~F})\end{array}$ & $\begin{array}{l}\text { - include up to two lags } \\
\text { - fixed effect estimation regressing } \\
\text { TFP on environmental policy } \\
\text { variable }\end{array}$ & $\begin{array}{l}\text { - overall, negative effect on MFP } \\
\text { - ozone regulations have strongest } \\
\text { contemporaneous negative effect, PM and SO } \\
\text { regulations strongest accumulated effect } \\
\text { - negative accumulated overall effect is larger than } \\
\text { contemporaneous effect }\end{array}$ \\
\hline Becker (2011) & $\begin{array}{l}\text { Labour } \\
\text { productivity }\end{array}$ & $\begin{array}{l}\text { Ratio of PACE to } \\
\text { economic activity }\end{array}$ & $\begin{array}{l}\text { American } \\
\text { manufacturing } \\
\text { industries, } 1980- \\
1994(F)\end{array}$ & $\begin{array}{l}\text { - fixed effect estimation of Cobb- } \\
\text { Douglas function including } \\
\text { compliance costs }\end{array}$ & $\begin{array}{l}\text { - no significant effect on productivity } \\
\text { - significant negative effect is found in sample } \\
\text { consisting only of plants which experienced } \\
\text { statistically meaningful changes in environmental } \\
\text { compliance costs }\end{array}$ \\
\hline $\begin{array}{l}\text { Broberg et al. } \\
(2013)\end{array}$ & $\begin{array}{l}\text { Efficiency } \\
\text { score derived } \\
\text { from StoFA }\end{array}$ & $\begin{array}{l}\text { Environmental } \\
\text { protection } \\
\text { investments } \\
\text { (distinguished into } \\
\text { pollution prevention } \\
\text { and pollution control) }\end{array}$ & $\begin{array}{l}\text { Four Swedish } \\
\text { manufacturing } \\
\text { industries, } 1999 \text { - } \\
2004(F)\end{array}$ & $\begin{array}{l}\text { - efficiency measure using translog } \\
\text { stochastic production frontier } \\
\text { model } \\
\text { - efficiency modelled as function of } \\
\text { regulatory proxy } \\
\text { - including up to two lags }\end{array}$ & $\begin{array}{l}\text { - no support for PH in overall manufacturing } \\
\text { industry } \\
\text { - negative effect in pulp and paper industry, mainly } \\
\text { driven by negative effect of lagged variables }\end{array}$ \\
\hline
\end{tabular}




\begin{tabular}{|c|c|c|c|c|c|}
\hline $\begin{array}{l}\text { Author and } \\
\text { year }\end{array}$ & Dep. variable & Independent variable & Sample & Methodology & Result \\
\hline $\begin{array}{l}\text { Van der Vlist et } \\
\text { al. (2007) }\end{array}$ & $\begin{array}{l}\text { Efficiency score } \\
\text { derived from } \\
\text { StoFA }\end{array}$ & $\begin{array}{l}\text { Dummies for relevant } \\
\text { environmental } \\
\text { policies }\end{array}$ & $\begin{array}{l}\text { Dutch horticulture } \\
\text { sector, } 1991 \text { - } \\
1999(F)\end{array}$ & $\begin{array}{l}\text { - estimation of stochastic } \\
\text { production frontier including } \\
\text { dummy variables of } \\
\text { environmental policies }\end{array}$ & $\begin{array}{l}\text { - positive effect on technical efficiency } \\
\text { - environmental policy regimes increased technical } \\
\text { efficiencies }\end{array}$ \\
\hline $\begin{array}{l}\text { Jaraité and Di } \\
\text { Maria (2012) }\end{array}$ & $\begin{array}{l}1 / \Delta \text { efficiency } \\
\text { score derived } \\
\text { from DEA }\end{array}$ & $\begin{array}{l}\text { Average annual spot } \\
\text { price of } \mathrm{CO}_{2} \\
\text { allowance } \\
\text { Ratio of initial permit } \\
\text { allocation to verified } \\
\text { emissions }\end{array}$ & $\begin{array}{l}24 \text { European } \\
\text { fossil-fuel based } \\
\text { public power } \\
\text { generating } \\
\text { sectors, } 1996 \text { - } \\
2007 \text { (F) }\end{array}$ & $\begin{array}{l}\text { - efficiency measure using DEA } \\
\text { incl. } \mathrm{CO}_{2} \text { and } \mathrm{SO} 2 \text { as bad outputs } \\
\text { - fixed effect estimation }\end{array}$ & $\begin{array}{l}\text { - adjusted efficiency score increases over time as } \\
\text { bad output was reduced but laxity of policy (low } \\
\mathrm{CO}_{2} \text { prices) partly offset the effect } \\
\text { - positive effect on technical change, negative effect } \\
\text { on technical efficiency }\end{array}$ \\
\hline $\begin{array}{l}\text { Fleishman et al. } \\
\text { (2009) }\end{array}$ & $\begin{array}{l}\text { Efficiency score } \\
\text { derived from } \\
\text { DEA }\end{array}$ & $\begin{array}{l}\text { Dummies for SOX } \\
\text { and NOX regulation }\end{array}$ & $\begin{array}{l}\text { American gas } \\
\text { and coal power } \\
\text { plants, } 1994 \text { - } \\
2004(F)\end{array}$ & $\begin{array}{l}\text { - efficiency measure using DEA } \\
\text { incl. bad outputs } \\
\text { - Tobit estimation }\end{array}$ & $\begin{array}{l}\text { - positive effect of SO2 regulations for coal and gas } \\
\text { plants } \\
\text { - negative effect of NOX regulation for gas plants } \\
\text { - effect driven by presence not stringency of } \\
\text { regulation } \\
\text { - using adjusted or traditional efficiency scores does } \\
\text { not alter the results }\end{array}$ \\
\hline $\begin{array}{l}\text { Managi et al. } \\
(2005)\end{array}$ & $\begin{array}{l}\Delta \text { Efficiency } \\
\text { score derived } \\
\text { from DEA }\end{array}$ & $\begin{array}{l}\text { Environmental } \\
\text { compliance cost }\end{array}$ & $\begin{array}{l}\text { American } \\
\text { offshore oil and } \\
\text { gas industry, } \\
1968-1988(F)\end{array}$ & $\begin{array}{l}\text { - efficiency measure using DEA } \\
\text { incl. bad outputs } \\
\text { - Almon distributed lag model and } \\
\text { Granger causality tests } \\
\text { - includes up to eight lags }\end{array}$ & $\begin{array}{l}\text { - negative effect in the short term } \\
\text { - } \text { positive effect in medium to long term } \\
\text { calculation shows no significant effect of } \\
\text { environmental regulation } \\
\text { - evidence that higher technological change of } \\
\text { market outputs leads to more stringent } \\
\text { environmental regulations }\end{array}$ \\
\hline $\begin{array}{l}\text { Boyd and } \\
\text { McClelland } \\
\text { (1999) }\end{array}$ & $\begin{array}{l}\text { Efficiency score } \\
\text { derived from } \\
\text { DEA }\end{array}$ & $\begin{array}{l}\text { Air and water } \\
\text { pollutants, toxics }\end{array}$ & $\begin{array}{l}\text { American } \\
\text { integrated paper } \\
\text { plants, } 1988 \text { - } \\
1992(\mathrm{~F})\end{array}$ & $\begin{array}{l}\text { - compares efficiency score under } \\
\text { the assumption of weak and free } \\
\text { disposability of bad outputs }\end{array}$ & $\begin{array}{l}\text { - positive effect of environmental regulation on } \\
\text { efficiency }\end{array}$ \\
\hline Gray (1987) & $\Delta \mathrm{TFP}$ & $\begin{array}{l}\text { PACE } \\
\text { Worker and health } \\
\text { regulation (number of } \\
\text { inspections) }\end{array}$ & $\begin{array}{l}450 \text { American } \\
\text { manufacturing } \\
\text { industries, } 1958- \\
1978 \text { (I) }\end{array}$ & $\begin{array}{l}\text { - uses growth accounting to } \\
\text { calculate productivity } \\
\text { - simple regression analysis }\end{array}$ & $\begin{array}{l}\text { - negative effect when regulation measures are } \\
\text { included separately without any covariates } \\
\text { - no significant effect when both regulations plus } \\
\text { other explanatory variables are included } \\
\text { - sensitivity tests render PACE coefficient } \\
\text { insignificant }\end{array}$ \\
\hline
\end{tabular}


ECO/WKP(2013)88

\begin{tabular}{|c|c|c|c|c|c|}
\hline $\begin{array}{c}\text { Author and } \\
\text { year }\end{array}$ & Dep. variable & Independent variable & Sample & Methodology & Result \\
\hline $\begin{array}{l}\text { Dufour et al. } \\
\text { (1998) }\end{array}$ & $\triangle T F P$ & $\begin{array}{l}\text { Investment in } \\
\text { pollution-control } \\
\text { equipment to total } \\
\text { input costs } \\
\text { worker and health } \\
\text { regulation }\end{array}$ & $\begin{array}{l}\text { Canadian } \\
\text { manufacturing } \\
\text { industries, } 1985 \text { - } \\
1988 \text { (I) }\end{array}$ & $\begin{array}{l}\text { - uses growth accounting to } \\
\text { calculate productivity } \\
\text { - GLS estimation, controlling for } \\
\text { economies of scale and business } \\
\text { cycle fluctuations }\end{array}$ & $\begin{array}{l}\text { - negative effect of environmental regulation } \\
\text { offect of worker health regulation depends on type } \\
\text { reassignments, positive effect of mandatory } \\
\text { prevention programs and fines) }\end{array}$ \\
\hline $\begin{array}{l}\text { Barbera and } \\
\text { McConnell } \\
\text { (1990) }\end{array}$ & $\triangle T F P$ & Abatement capital & $\begin{array}{l}\text { Five American } \\
\text { manufacturing } \\
\text { industries, } 1960 \text { - } \\
1980 \text { (I) }\end{array}$ & $\begin{array}{l}\text { - estimating cost elasticity of } \\
\text { abatement capital } \\
\text { - differentiate direct and indirect } \\
\text { effect: } \\
\text { - direct effect comes through } \\
\text { changes in costs and their effect } \\
\text { on productivity } \\
\text { - disentangling effect of abatement } \\
\text { capital costs on } \Delta T F P \text { yields } \\
\text { indirect effect }\end{array}$ & $\begin{array}{l}\text { - } \text { small indirect effect (positive/negative) } \\
\text { negative direct effect (as long as abatement } \\
\text { - } \text { negative news) } \\
\end{array}$ \\
\hline $\begin{array}{l}\text { Hamamoto } \\
\text { (2006) }\end{array}$ & TFP & $\begin{array}{l}\text { Induced R\&D } \\
\text { (derived from } \\
\text { pollution abatement } \\
\text { capital cost effect on } \\
\text { R\&D spending) }\end{array}$ & $\begin{array}{l}\text { Five Japanese } \\
\text { manufacturing } \\
\text { industries, } 1966 \text { - } \\
1982(\mathrm{I})\end{array}$ & $\begin{array}{l}\text { - } \text { elasticity of R\&D expenditure } \\
\text { w.r.t. lagged regulatory stringency } \\
\text { is used to calculate induced R\&D } \\
\text { - extended (standard inputs plus } \\
\text { R\&D capital) Cobb-Douglas } \\
\text { production function is used to } \\
\text { examine effect on productivity } \\
\text { growth } \\
\text { - includes up to six lags }\end{array}$ & $\begin{array}{l}\text { - negative effect of PACE on age of capital stock } \\
\text { which in turn does not affect TFP growth rate } \\
\text { - positive effect of PACE on R\&D expenditure and } \\
\text { induced R\&D positively affects TFP growth } \\
\text { - longest lag structure model performs best }\end{array}$ \\
\hline $\begin{array}{l}\text { Yang et al. } \\
\text { (2012) }\end{array}$ & TFP & $\begin{array}{l}\text { R\&D induced by } \\
\text { environmental } \\
\text { regulation (calculated } \\
\text { through abatement } \\
\text { capital costs and } \\
\text { pollution abatement } \\
\text { fees) }\end{array}$ & $\begin{array}{l}\text { Taiwanese } \\
\text { manufacturing } \\
\text { industries, } 1997 \text { - } \\
2003 \text { (I) }\end{array}$ & $\begin{array}{l}\text { - use Levinsohn and Petrin (2003) } \\
\text { productivity measure } \\
\text { - fixed effect estimation } \\
\text { - include one lag }\end{array}$ & $\begin{array}{l}\text { - } \text { positive effect of induced R\&D on TFP } \\
\text { - effect of induced R\&D is smaller than of } \\
\text { scheduled R\&D } \\
\text { - positive effect of environmental regulation on R\&D } \\
\text { - positive direct effect of environmental regulation } \\
\text { on TFP (larger for pollution control fees than for } \\
\text { PACE) }\end{array}$ \\
\hline $\begin{array}{l}\text { Lanoie et al. } \\
\text { (2008) }\end{array}$ & $\triangle T F P$ & $\begin{array}{l}\text { Investment in } \\
\text { pollution-control } \\
\text { equipment to total } \\
\text { input costs }\end{array}$ & $\begin{array}{l}\text { Canadian } \\
\text { manufacturing } \\
\text { industries } \\
\text { (Quebec), } 1985 \text { - } \\
1994 \text { (I) }\end{array}$ & $\begin{array}{l}\text { - up to three years of lagged } \\
\text { regulatory variable } \\
\text { - GLS estimation }\end{array}$ & $\begin{array}{l}\text { - negative contemporaneous effect } \\
\text { - positive effect of second and third lag (outweighs } \\
\text { initial negative effect) } \\
\text { - effect stronger in sectors which face more } \\
\text { international competition }\end{array}$ \\
\hline
\end{tabular}


ECO/WKP(2013)88

\begin{tabular}{|c|c|c|c|c|c|}
\hline $\begin{array}{c}\text { Author and } \\
\text { year }\end{array}$ & Dep. variable & Independent variable & Sample & Methodology & Result \\
\hline $\begin{array}{l}\text { Domazlicky and } \\
\text { Weber (2004) }\end{array}$ & $\begin{array}{l}\Delta \text { Efficiency } \\
\text { score derived } \\
\text { from DEA }\end{array}$ & $\begin{array}{l}\text { Emission into air, } \\
\text { water, land or } \\
\text { underground }\end{array}$ & $\begin{array}{l}\text { Six American } \\
\text { chemical } \\
\text { industries, } 1988- \\
1993(I)\end{array}$ & $\begin{array}{l}\text { compares efficiency score under } \\
\text { the assumption of weak and free } \\
\text { disposability of bad outputs }\end{array}$ & $\begin{array}{l}\text { - } \text { positive effect on productivity growth } \\
\text { - } \text { significantly different from each other } \\
\text { - no correlation of abatement costs and } \\
\text { productivity growth found }\end{array}$ \\
\hline $\begin{array}{l}\text { Alpay et al. } \\
\text { (2002) }\end{array}$ & $\triangle \mathrm{TFP}$ & $\begin{array}{l}\text { - Pollution } \\
\text { abatement costs } \\
\text { (US) } \\
\text { - Frequency of } \\
\text { reported plant } \\
\text { inspections } \\
\text { (Mexico) }\end{array}$ & $\begin{array}{l}\text { Mexican and U.S. } \\
\text { food sector, } 1962 \\
-1994 \text { (I) }\end{array}$ & $\begin{array}{l}\text { - use elasticities to calculate } \\
\text { contribution of environmental } \\
\text { regulation to productivity growth } \\
\text { - calculates TFP growth with and } \\
\text { without abatement costs }\end{array}$ & $\begin{array}{l}\text { - positive effect on productivity growth in Mexico, } \\
\text { no significant effect in the US } \\
\text { - negative effect on profitability in Mexico, no } \\
\text { significant effect in the US } \\
\text { - larger productivity growth rates in Mexico when } \\
\text { environmental regulation is included in } \\
\text { productivity calculation, US show slightly lower } \\
\text { productivity growth rates }\end{array}$ \\
\hline $\begin{array}{l}\text { Jeon and } \\
\text { Sickles (2004) }\end{array}$ & $\begin{array}{l}\Delta \text { Efficiency } \\
\text { score derived } \\
\text { from DEA }\end{array}$ & $\mathrm{CO}_{2}$ emissions & $\begin{array}{l}17 \text { OECD and } 11 \\
\text { Asian economies, } \\
1980-1995(M)\end{array}$ & $\begin{array}{l}\text { compares efficiency scores of } \\
\text { three scenarios (free emission, no } \\
\text { change of emission levels, partial } \\
\text { reduction of emissions) }\end{array}$ & $\begin{array}{l}\text { - adjusted TFP growth is lower than traditional for } \\
\text { OECD countries whereas it is higher for ASEAN } \\
\text { countries } \\
\text { - productivity growth is lower in constant emission } \\
\text { scenario then in free emissions scenario for } \\
\text { OECD and ASEAN economies } \\
\text { - productivity growth is higher in scenario of } \\
\text { emission reduction in OECD and ASEAN } \\
\text { economies }\end{array}$ \\
\hline $\begin{array}{l}\text { Wu and Wang } \\
\text { (2008) }\end{array}$ & $\begin{array}{l}\Delta \text { Efficiency } \\
\text { score derived } \\
\text { from DEA }\end{array}$ & $\mathrm{CO}_{2}$ emissions & $\begin{array}{l}17 \text { APEC } \\
\text { economies, } 1980 \\
\text { - } 2004 \text { (M) }\end{array}$ & $\begin{array}{l}\text { - compares efficiency scores of } \\
\text { three scenarios (free emission, no } \\
\text { change of emission levels, partial } \\
\text { reduction of emissions) } \\
\text { - fixed effect regression of dummy } \\
\text { marking years of UNFCCC } \\
\text { ratification on productivity growth }\end{array}$ & $\begin{array}{l}\text { - productivity growth slightly higher in scenario of } \\
\text { no change and reduction of emission levels than } \\
\text { in free emission scenario } \\
\text { - negative effect of ratification of UNFCCC on } \\
\text { productivity growth }\end{array}$ \\
\hline $\begin{array}{l}\text { Yörük and Zaim } \\
\text { (2005) }\end{array}$ & $\begin{array}{l}\Delta \text { Efficiency } \\
\text { score derived } \\
\text { from DEA } \\
\text { (CO2, NOX and } \\
\text { water } \\
\text { pollutants) }\end{array}$ & $\begin{array}{l}\text { UNFCCC protocol } \\
\text { ratification }\end{array}$ & $\begin{array}{l}\text { OECD } \\
\text { economies, } 1983 \\
-1998(\mathrm{M})\end{array}$ & $\begin{array}{l}\text { - } \text { compares traditional with adjusted } \\
\text { productivity index (emission } \\
\text { reduction scenario) } \\
\text { - fixed effect regression of dummy } \\
\text { marking years of UNFCCC } \\
\text { ratification on adjusted productivity } \\
\text { growth }\end{array}$ & $\begin{array}{l}\text { - adjusted productivity growth is significantly larger } \\
\text { than traditional } \\
\text { - effect of NOX and water pollutants is largest } \\
\text { - significant positive effect of UNFCCC ratification } \\
\text { on adjusted MFP growth (no effect on traditional } \\
\text { MFP growth) }\end{array}$ \\
\hline
\end{tabular}


ECO/WKP(2013)88

\begin{tabular}{|c|c|c|c|c|c|}
\hline $\begin{array}{c}\text { Author and } \\
\text { year }\end{array}$ & Dep. variable & Independent variable & Sample & Methodology & Result \\
\hline \multicolumn{6}{|l|}{ Innovation } \\
\hline $\begin{array}{l}\text { Johnstone and } \\
\text { Labonne (2006) }\end{array}$ & $\begin{array}{l}\text { Environmental } \\
\text { R\&D } \\
\text { expenditure }\end{array}$ & $\begin{array}{l}\text { Compiled } \\
\text { environmental } \\
\text { stringency indicator } \\
\text { (survey data) }\end{array}$ & $\begin{array}{l}7 \text { OECD } \\
\text { manufacturing } \\
\text { sectors, } 2003(F)\end{array}$ & $\begin{array}{l}\text { - } \text { survey data } \\
\text { - } \text { probit estimation }\end{array}$ & $\begin{array}{l}\text { - } \text { positive effect of environmental taxes on } \\
\text { environmental R\&D expenditure } \\
\text { - negative effect of technology-based standards }\end{array}$ \\
\hline $\begin{array}{l}\text { Arimura et al. } \\
(2007)\end{array}$ & $\begin{array}{l}\text { Environmental } \\
\text { R\&D } \\
\text { expenditure }\end{array}$ & $\begin{array}{l}\text { Compiled } \\
\text { environmental } \\
\text { stringency indicator } \\
\text { (survey data) }\end{array}$ & $\begin{array}{l}7 \text { OECD } \\
\text { manufacturing } \\
\text { sectors, } 2003(F)\end{array}$ & $\begin{array}{l}\text { - survey data } \\
\text { - tobit and bivariate probit estimation }\end{array}$ & $\begin{array}{l}\text { - positive effect of perceived policy stringency on } \\
\text { environmental R\&D expenditure } \\
\text { - no support for stronger effect of flexible policy } \\
\text { instruments }\end{array}$ \\
\hline $\begin{array}{l}\text { Lanoie et al. } \\
\text { (2011) }\end{array}$ & $\begin{array}{l}\text { Environmental } \\
\text { R\&D } \\
\text { Environmental } \\
\text { and business } \\
\text { performance }\end{array}$ & $\begin{array}{l}\text { Compiled } \\
\text { environmental } \\
\text { stringency indicator } \\
\text { (survey data) }\end{array}$ & $\begin{array}{l}7 \text { OECD } \\
\text { manufacturing } \\
\text { sectors, } 2003(F)\end{array}$ & $\begin{array}{l}\text { - uses survey data (Heckman } \\
\text { sample selection procedure) } \\
\text { - tests all versions of Porter } \\
\text { Hypothesis in one common } \\
\text { framework } \\
\text { - } \quad \text { probit, 2SLS, instrumental variable } \\
\text { probit estimation }\end{array}$ & $\begin{array}{l}\text { - support for weak and narrow version of } \mathrm{PH}, \text { no } \\
\text { support for strong version } \\
\text { - effect of environmental taxes is driven by } \\
\text { stringency of taxes } \\
\text { - stringency of performance standards has larger } \\
\text { impact than technology based standards } \\
\text { - direct effect on business performance is } \\
\text { negative and larger than indirect positive effect }\end{array}$ \\
\hline $\begin{array}{l}\text { Jaffe and } \\
\text { Palmer (1997) }\end{array}$ & $\begin{array}{l}\text { Total R\&D } \\
\text { expenditure } \\
\text { Number of } \\
\text { successful } \\
\text { patent }\end{array}$ & PACE & $\begin{array}{l}\text { US } \\
\text { manufacturing } \\
\text { industries, } 1975 \text { - } \\
1991 \text { (I) }\end{array}$ & $\begin{array}{l}\text { - pooled model and fixed effects } \\
\text { - inclimation } \\
\text { - inclung up to five lags }\end{array}$ & $\begin{array}{l}\text { - positive effect on R\&D expenditure of lagged } \\
\text { PACE } \\
\text { - no effect of PACE on number of successful } \\
\text { patents }\end{array}$ \\
\hline $\begin{array}{l}\text { Brunnermeier } \\
\text { and Cohen } \\
(2003)\end{array}$ & $\begin{array}{l}\text { Environmental } \\
\text { patents }\end{array}$ & $\begin{array}{l}\text { PACE } \\
\text { Number of } \\
\text { inspections }\end{array}$ & $\begin{array}{l}146 \text { US } \\
\text { manufacturing } \\
\text { industries, } 1983- \\
1992(\mathrm{I})\end{array}$ & $\begin{array}{l}\text { - different estimation models: fixed } \\
\text { effect, Poisson count data model, } \\
\text { negative binominal fixed and } \\
\text { random effects }\end{array}$ & $\begin{array}{l}\text { - positive effect of PACE on number of patents } \\
\text { - insignificant results for number of inspections } \\
\text { in industries which are exposed to international } \\
\text { competition }\end{array}$ \\
\hline $\begin{array}{l}\text { Kneller and } \\
\text { Manderson } \\
(2012)\end{array}$ & $\begin{array}{l}\text { R\&D } \\
\text { expenditure } \\
\text { Total R\&D } \\
\text { activity }\end{array}$ & $\begin{array}{l}\text { Environmental } \\
\text { protection } \\
\text { expenditures }\end{array}$ & $\begin{array}{l}\text { UK } \\
\text { manufacturing } \\
\text { industries, } 2000- \\
2006 \text { (I) }\end{array}$ & $\begin{array}{l}\text { - } \quad \text { GMM estimation } \\
\text { - include up to two lags }\end{array}$ & $\begin{array}{l}\text { - positive effect on environmental R\&D and } \\
\text { investment in environmental capital, no effect on } \\
\text { overall R\&D or total capital accumulation } \\
\text { - environmental R\&D may crowd out non- } \\
\text { environmental R\&D } \\
\text { - no evidence of crowding out effect of } \\
\text { environmental capital }\end{array}$ \\
\hline
\end{tabular}


ECO/WKP(2013)88

\begin{tabular}{|c|c|c|c|c|c|}
\hline $\begin{array}{l}\text { Author and } \\
\text { year }\end{array}$ & Dep. variable & Independent variable & Sample & Methodology & Result \\
\hline $\begin{array}{l}\text { Lanjouw and } \\
\text { Mody (1996) }\end{array}$ & Patent counts & PACE & $\begin{array}{l}\text { US, Japanese } \\
\text { and German } \\
\text { economies, } 1971 \\
-1988(\mathrm{M})\end{array}$ & $\begin{array}{l}\text { - evaluate effect of pollution } \\
\text { abatement capital expenditure on } \\
\text { patent count with simple time- } \\
\text { series correlation }\end{array}$ & 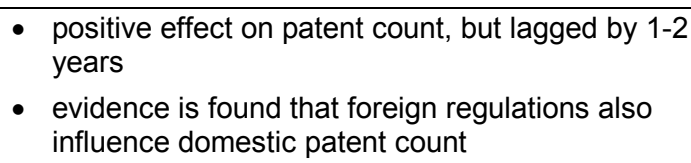 \\
\hline Popp (2006) & $\begin{array}{l}\text { Environmental } \\
\text { patents }\end{array}$ & $\begin{array}{l}\text { SOX and NOX } \\
\text { regulations }\end{array}$ & $\begin{array}{l}\text { US, Japanese } \\
\text { and German } \\
\text { economies, } 1967 \\
-2003(\mathrm{M})\end{array}$ & $\begin{array}{l}\text { evaluates effect of domestic and } \\
\text { foreign regulation on innovation } \\
\text { with simple time-series correlation }\end{array}$ & $\begin{array}{l}\text { inventors respond to environmental regulation } \\
\text { pressure in their own country but not to foreign } \\
\text { environmental regulation }\end{array}$ \\
\hline $\begin{array}{l}\text { Johnstone et al. } \\
2010 a\end{array}$ & $\begin{array}{l}\text { Patent counts } \\
\text { in renewable } \\
\text { energy sectors }\end{array}$ & $\begin{array}{l}\text { Renewable energy } \\
\text { policy variables }\end{array}$ & $\begin{array}{l}25 \text { OECD } \\
\text { countries, } 1978- \\
2003(\mathrm{M})\end{array}$ & $\begin{array}{l}\text { - panel estimated with a negative } \\
\text { binomial model, } \\
\text { - fixed effects are included, } \\
\text { - } 3 \text { of } 6 \text { policy variables are modelled } \\
\text { with dummies (introduced or not) }\end{array}$ & $\begin{array}{l}\text { - renewable energy policies have a significant } \\
\text { effect on related patents, } \\
\text { - feed-in-tariffs have an additional positive effect } \\
\text { on solar power patents, renewable energy } \\
\text { certificates have a positive effect on wind energy } \\
\text { patents. }\end{array}$ \\
\hline $\begin{array}{l}\text { Johnstone et al. } \\
2010 \mathrm{~b}\end{array}$ & $\begin{array}{l}\text { Environmental } \\
\text { patent counts }\end{array}$ & $\begin{array}{l}\text { Perceptions of } \\
\text { environmental policy } \\
\text { stringency, flexibility } \\
\text { and predictability } \\
\text { (WEF survey) }\end{array}$ & $\begin{array}{l}\text { OECD countries, } \\
2000-2007 \text { (M) }\end{array}$ & $\begin{array}{l}\text { - panel estimated with a negative } \\
\text { binomial model, } \\
\text { - due to high collinearity of the policy } \\
\text { variables, orthogonal factors are } \\
\text { extracted, } \\
\text { - no fixed effects are included }\end{array}$ & $\begin{array}{l}\text { - policy stringency, flexibility and stability have a } \\
\text { positive coefficient (weak } \mathrm{PH} \text { ). }\end{array}$ \\
\hline $\begin{array}{l}\text { De Vries and } \\
\text { Withagen } \\
\text { (2005) }\end{array}$ & $\begin{array}{l}\text { Environmental } \\
\text { patents }\end{array}$ & $\begin{array}{l}\text { Dummy variable for } \\
\text { regulations }\end{array}$ & $\begin{array}{l}14 \text { OECD } \\
\text { economies, } 1970 \\
-2000 \text { (M) }\end{array}$ & $\begin{array}{l}\text { - instrumental variable approach } \\
\text { - fixed effect estimation }\end{array}$ & - large positive effect on patent count \\
\hline $\begin{array}{l}\text { Kalamova and } \\
\text { Johnstone } \\
\text { (2011) }\end{array}$ & $\begin{array}{l}\text { Bilateral FDI } \\
\text { flows }\end{array}$ & $\begin{array}{l}\text { Perceived } \\
\text { environmental policy } \\
\text { stringency index } \\
\text { (WEF) }\end{array}$ & $\begin{array}{l}27 \text { OECD } \\
\text { countries + } 99 \\
\text { host countries, } \\
2001-2007(M)\end{array}$ & $\begin{array}{l}\text { panel estimation with controls for } \\
\text { drivers of FDI }\end{array}$ & $\begin{array}{l}\text { - positive effect of lax environmental stringency on } \\
\text { FDI inflows } \\
\text { - non-linear effect: FDI inflows decrease after a } \\
\text { certain threshold of laxity is reached }\end{array}$ \\
\hline \multicolumn{6}{|c|}{ Investment and capital stock } \\
\hline $\begin{array}{l}\text { Gray and } \\
\text { Shadbegian } \\
\text { (1998) }\end{array}$ & Investment & PACE & $\begin{array}{l}\text { American paper } \\
\text { mills, } 1979-1990 \\
(\mathrm{~F})\end{array}$ & $\begin{array}{l}\text { - different regression specifications, } \\
\text { including dummies for high } \\
\text { pollution abatement investment } \\
\text { years and a variable which divides } \\
\text { total plant abatement investment } \\
\text { over time }\end{array}$ & $\begin{array}{l}\text { - } \\
\text { slants with high abatement investment spend } \\
\text { out effect. For one dollar spend on } \\
\text { environmental capital reduces investment into } \\
\text { productive capital by } 1.88 \text {. } \\
\text { - effect is } 0.99 \text { when adjusted for within firm } \\
\text { (across plant) allocation. }\end{array}$ \\
\hline
\end{tabular}


ECO/WKP(2013)88

\begin{tabular}{|c|c|c|c|c|c|}
\hline $\begin{array}{c}\text { Author and } \\
\text { year }\end{array}$ & Dep. variable & Independent variable & Sample & Methodology & Result \\
\hline $\begin{array}{l}\text { Nelson et al. } \\
\text { (1993) }\end{array}$ & $\begin{array}{l}\text { Age of capital } \\
\text { stock }\end{array}$ & $\begin{array}{l}\text { - Enforcement costs } \\
\text { of environmental } \\
\text { agency } \\
\text { - value of pollution } \\
\text { control facilities }\end{array}$ & $\begin{array}{l}\text { US electric } \\
\text { utilities, } 1969- \\
1983(F)\end{array}$ & - 3SLS estimation & $\begin{array}{l}\text { - positive effect on age of capital stock } \\
\text { - increase in age of capital does not impact } \\
\text { emission level }\end{array}$ \\
\hline
\end{tabular}




\section{BIBLIOGRAPHY}

Adams, J. (1997), Environmental policy and competitiveness in a globalised economy: Conceptual issues and a review of the empirical evidence. In: Globalisation and environment: Preliminary perspectives. Paris: OECD.

Ambec, S., M. A. Cohen, S. Elgie and P. Lanoie (2013), "The Porter Hypothesis at 20: Can Environmental Regulation Enhance Innovation and Competitiveness?", Review of Environmental Economics and Policy, Vol. 7(1), pp. 2-22.

Alpay, E., S. Buccola and J. Kerkvliet (2002), "Productivity Growth and Environmental Regulation in Mexican and U.S. Food Manufacutring", American Journal of Agricultural Economics, Vol. 84(4), pp. 887-901.

Arimura, T., A. Hibiki and N. Johnstone (2007), "An empirical study of environmental R\&D: What encourages facilities to be environmentally innovative?", in Corporate behaviour and environmental policy, ed. N. Johnstone, Cheltenham, UK.

Barbera, A. J. and V. D. McConnell (1990), "The Impact of Environmental Regulations on Industry Productivity: Direct and Indirect Effects", Journal of Environmental Economics and Management, Vol. 18, pp. 50-65.

Becker, R. A. (2011), "Local environmental regulation and plant-level productivity", Ecological Economics, Vol. 70, pp. 2513-2522.

Becker and Shadbegian (2004), "Comparing the 1994 and 1999 Pollution Abatement Costs and Expenditures Surveys", NCEE Working Paper, Number: 04-08.

Berman, E. and L. T. M. Bui (2001a), "Environmental Regulation and Productivity: Evidence from Oil Refineries", The Review of Economics and Statistics, Vol. 83(3), pp. 498-510.

Berman, E. and L. T. M. Bui (2001b), "Environmental Regulation and Labor Demand: Evidence from the South Coast Air Basin", Journal of Public Economics, Vol. 79, pp. 265-295.

Boyd, G. A. and J. D. McClelland (1999), "The Impact of Environmental Constraints on Productivity Improvement in Integrated paper Plants", Journal of Environmental Economics and Management, Vol. 38, pp. 121-142.

Botta, E. (2014), "Indicators of environmental policy stringency", OECD, forthcoming.

Brandt, N., P. Schreyer and V. Zipperer (2013), "A Green Productivity Measure with Natural Capital and Bad Output", OECD Economics Working Paper. 
Brännlund, R. and T. Lundgren (2009), "Environmental Policy Without Costs? A Review of the Porter Hypothesis", International Review of Environmental and Resource Economics, Vol. 3, pp. 75-117.

Broberg, T., P.-O. Marklund, E. Samakovlis and H. Hammar (2012), "Testing the Porter hypothesis: the effects of environmental investments on efficiency in Swedish industry", Journal of Productivity Analysis, Vol. 40(1), pp. 43-56.

Brunel, C. and A. Levinson (2013), "Measuring Environmental Regulatory Stringency", Working Paper, Georgetown University.

Brunnermeier, S. B. and M. A. Cohen (2003), "Determinants of environmental innovation in US manufacturing industries", Journal of Environmental Economics and Management, Vol. 45, pp. 278293.

Brunnermeier, S. G. and A. Levinson (2004), "Examining the evidence on environmental regulation and industry location", Journal of Environment and Development, Vol. 13(6), pp. 6-41.

Christainsen, G. B. and R. H. Haveman (1981), "Public Regulations and the Slowdown in Productivity Growth", The American Economic Review, Vol. 71(2), pp. 320-325.

Cole, M. A. and R. J. Elliot (2003), "Do Environmental Regulations Influence Trade Patterns? Testing Old and New Trade Theories", The World Economy, Vol. 26(8), pp. 1163-1186.

Copeland, B. R. and M. S. Taylor (2004), "Trade, Growth and the Environment", Journal of Economic Literature, Vol. 42, pp. 7-71.

Curtis, M. (2012), "Who Loses under Power Plant Cap-and-Trade Programs? Estimating the Impact of the $\mathrm{NO}_{\mathrm{X}}$ Budget Trading Program on Manufacturing Employment", Working Paper Georgia State University, Georgia.

De Serres, A., F. Murtin and G. Nicoletti (2010), "A Framework for Assessing Green Growth Policies", OECD Economics Department Working Papers, No. 774, OECD Publishing.

De Vries, F. P. and C. Withagen (2005), "Innovation and environmental stringency: the case of sulphur dioxide abatement", Discussion Paper Tilburg University, Tilburg.

Domazlicky, B. R. and W. L. Weber (2004), "Does Environmental Protection Lead to Slower Productivity Growth in the Chemical Industry?", Environmental and Resource Economics, Vol. 28, pp. 301-324.

Dufour, C., P. Lanoie and M. Patry (1998), "Regulation and productivity", Journal of Productivity Analysis, Vol. 9(3), pp. 233-247.

Fleishman, R., R. Alexander, S. Bretschneider and D. Popp (2009), "Does regulation stimulate productivity? The effect of air quality policies on the efficiency of US power plants", Energy Policy, Vol. 37, pp. 4574-4582.

Gollop, F. M. and M. J. Roberts (1983), "Environmental Regulations and Productivity Growth: The Case of Fossil-fueled Electric Power Generation", Journal of Political Economy, Vol. 91(4), pp. 654-674.

Graff Zivin, J. and M. Neidel (2012), "The Impact of Pollution on Worker Productivity", American Economic Review, Vol. 102(7), pp. 3652-73. 
Gray, W. B. (1987), "The Cost of Regulation: OSHA, EPA and the Productivity Slowdown", The American Economic Review, Vol. 77(5), pp. 998-1006.

Gray, W. B. (1997), “Manufacturing Plant Location: Does State Pollution Regulation Matter?", NBER Working Paper Series 5880, National Bureau of Economic Research, Cambridge Massachusetts.

Gray, W. B. and R. J. Shadbegian (1998), "Environmental Regulation, Investment Timing, and Technology Choice", The Journal of Industrial Economics, Vol. 46, pp. 235-256.

Gray, W. B. and R. J. Shadbegian (2003), "Plant vintage, technology, and environmental regulation", Journal of Environmental Economics and Management, Vol. 46, pp. 384-402.

Gray, W. B. and R. J. Shadbegian (2005), "Pollution abatement expenditures and plant-level productivity: A production function approach”, Ecological Economics, Vol. 54, pp. 196-208.

Greenstone, M., J. List and C. Syverson (2012), "The effects of environmental regulation on the competitiveness of U.S. manufacturing", NBER Working Paper Series 18392, National Bureau of Economic Research, Cambridge Massachusetts.

Hamamoto, M. (2008), "Environmental regulation and the productivity of Japanese manufacturing industries", Resource and Energy Economics, Vol. 28, pp. 299-312.

Harris, M., L. Konya and L. Matyas (2003), "Modelling the Impact of Environmental Regulations on Bilateral Trade Flows: OECD, 1990-1996”, World Economy, Vol. 25(3), pp. 387-405.

Heyes (2013), "Path Dependence, Firm Entry-Exit and the Environment", OECD, forthcoming.

Hicks, J. R. (1932), “The Theory of Wages”, Mcmilland \& Co, London.

Jaffe, A. B, S. R. Peterson, P. R. Portney and R. N. Stavins (1995), "Environmental Regulation and the Competitiveness of U.S. Manufacturing: What Does the Evidence Tell Us?", Journal of Economic Literature, Vol. 33(1), pp. 132-163.

Jaffe, A. B., R. G. Newell and R. N. Stavins (2003), "Technological change and the environment", Handbook of environmental economics, Vol.1, pp. 461-516.

Jaffe, A. B. and K. Palmer (1997), "Environmental Regulation and Innovation: A Panel Data Study", The Review of Economics and Statistics, Vol. 79(4), pp. 610-619.

Jaraité, J. and C. Di Maria (2012), "Efficiency, productivity and environmental policy: A case study of power generation in the EU", Energy Economics, Vol. 34, pp. 1557-1568.

Jeon, B. M. and R. C. Sickles (2004), "The Role of Environmental Factors in Growth Accounting", Journal of Applied Econometrics, Vol. 19, pp. 567-591.

Johnstone, N. and J. Labonne (2006), "Environmental policy, Management and R\&D”, OECD Economic Studies, Vol. 42, pp. 169-203.

Johnstone, N., I. Hascic and D. Popp (2010a), "Renewable Energy Policies and Technological Innovation: Evidence Based on Patent Counts", Environmental and Resource Economics, Vol. 45, pp. 133-155. 
Johnstone, N., I. Haščič and M. Kalamova (2010b), "Environmental Policy Design Characteristics and Technological Innovation: Evidence from Patent Data", OECD Environment Working Papers, No. 16, OECD Publishing.

Kalamova, M. and N. Johnstone (2011), "Environmental Policy Stringency and Foreign Direct Investment", OECD Environment Working Papers, No. 33.

Koźluk, T. (2014), "The indicator of economic burdens of environmental policy design - results from the OECD questionnaire", OECD forthcoming.

Kneller, R. and E. Manderson (2012), "Environmental regulations and innovation activity in UK manufacturing industries", Resource and Energy Economics, Vol. 34, pp. 211-235.

Krugman, P. R. (1994), “Competitiveness - a dangerous obsession”, Foreign Affairs, Vol. 73 (2), pp. 2844.

Lanjouw, J. O. and A. Mody (1996), "Innovation and the international diffusion of environmentally responsive technology", Research Policy, Vol. 25(5), pp. 549-571.

Lanoie, P., M. Patry and R. Lajeunesse (2008), "Environmental regulation and productivity: testing the porter hypothesis", Journal of Productivity Analysis, Vol. 30, pp. 121-128.

Lanoie, P., J. Laurent-Lucchetti, N. Johnstone and S. Ambec (2011), "Environmental Policy, Innovation and Performance: New Insights on the Porter Hypothesis", Journal of Economics and Management Strategy, Vol. 20(3), pp. 803-842.

Levinson, J. and A. Petrin (2003), "Estimating Production Functions Using Inputs to Control for Unobservables", Review of Economic Studies, Vol. 70, pp. 317-341.

Managi, S., J. J. Opaluch, D. Jin and T. A. Grigalunas (2005), "Environmental Regulations and Technological Change in the Offshore Oil and Gas Industry", Land Economics, Vol. 81(2), pp. 303319.

McConnell, V. and R. Schwab (1990), "The Impact of Environmental Regulation on Industry Location Decisions: The Motor Vehicle Industry", Land Economics, Vol. 66(1), pp. 67-81.

Mohr, R. D. and S. Saha (2008), "Distribution of environmental costs and benefits, additional distortions and the Porter Hypothesis", Land Economics, Vol. 84(4), pp. 689-700.

Morgenstern, R. D., W. A. Pizer and J.-S. Shih (2002), "Jobs Versus the Environment: An Industry-level Perspective", Journal of Environmental Economics and Management, Vol. 43, pp. 412-436.

Nelson, R. A., T. Tietenberg and M. R. Donihue (1993), "Differential environmental regulation: Effects on electric utility capital turnover and emissions", Review of Economics and Statistics, Vol. 75(2), pp. $368-373$.

Nicoletti, G., S. Scarpetta and O. Boylaud (2000), "Summary Indicators of Product Market Regulation with an Extension to Employment Protection Legislation", OECD Economics Department Working Papers, No. 226, OECD Publishing.

OECD (2006), Environmental Regulation and Competition - Policy Roundtable, DAF/COMP(2006)30. 
OECD (2007), "Pollution abatement and control expenditure in OECD countries", Environmental Policy Committee, Working Group on Environmental Information and Outlooks ENV/EPOC/SE(2007)1

OECD (2010), "Linkages between Environmental Policy and Competitiveness", OECD Environment Working Papers, No. 13, OECD Publishing.

OECD (2013), "The stringency of environmental regulations and trade in environmental goods and services", OECD forthcoming.

Ostro, B. D. (1983), "The Effects of Air Pollution on Work Loss and Morbidity", Journal of Environmental Economics and Management, Vol. 10(4), pp. 371-82.

Popp, D. (2006), "International innovation and diffusion of air pollution control technologies: the effects of $\mathrm{NO}_{\mathrm{X}}$ and $\mathrm{SO}_{2}$ regulation in the U.S., Japan, and Germany", Journal of Environmental Economics and Management, Vol. 51, pp. 46-71.

Porter, M. (1991), “America’s green strategy“, Scientific American, Vol. 264(4), p.168.

Porter, M. E. and C. van der Linde (1995), "Toward a New Conception of the Environment Competitiveness Relationship", Journal of Economic Perspectives, Vol. 9(4), pp. 97-118.

Repetto, R., D. Rothman, P. Faeth and D. Austin (1997), "Has Environmental Protection Really Reduced Productivity “, Challenge, Vol. 40(1), pp. 46-57.

Romstad, E. (1998), "Environmental Regulation and Competitiveness", in: Barker, T. \& Koehler, J. (eds.) International Competitiveness and Environmental Policies, pp. 185-196. Edward Elgar Publishers, Aldershot, England.

Rose, A. (1983), "Modeling the Macroeconomic Impact of Air Pollution Abatement", Journal of Regional Science, Vol. 23(4), pp. 441-459.

Shadbegian, R. J. and W. B. Gray (2005), "Pollution abatement expenditures and plant-level productivity: A production function approach”, Ecological Economics, Vol. 54, pp. 196-208.

Smarzynska, B.J. and S. J. Wei (2004), "Pollution Havens and Foreign Direct Investment: Dirty Secret or Popular Myth?", The B.E. Journal of Economic Analysis and Policy, Vol. 2, p. 8.

Smith, J. B. and W. A. Sims (1985), "The impact of pollution charges on productivity growth in Canadian brewing", The RAND Journal of Economics, Vol. 16(3), pp. 410-423.

Testa, F., F. Iraldo and M. Frey (2011), “The effect of environmental regulation on firms' competitive performance: The case of the building \& construction sector in some EU regions", Vol. 92, pp. 2136-2144.

Van Beers, C. and J. Van den Bergh (1997), "An Empirical Multi-Country Analysis of the Impact of Environmental Regulations on Foreign Trade Flows", KYKLOS, Vol. 50(1), pp. 29-46.

Van der Vlist, A. J., C. Withagen and H. Folmer (2007), "Technical efficiency under alternative environmental regulatory regimes: The case of Dutch horticulture", Ecological Economics, Vol. 63, pp. 165-173. 
Wagner, M. (2003), "The Porter Hypothesis revisited: A literature Review of theoretical Models and Empirical tests", Research Memorandum Centre for Sustainability Management University of Lüneburg, Lüneburg Germany.

WEF (2013), The Global Competitiveness Report 2012-2013, World Economic Forum, Geneva.

Wu, Y. and B. Wang (2008), "Environmental Regulation and Total Factor Productivity Growth: An Empirical Study of the APEC Economies", Economic Research Journal, Vol. 5, pp. 19-33.

Xepapades, A. and A. de Zeeuw (1999), "Environmental Policy and Competitiveness: The Porter Hypothesis and the Composition of Capital", Journal of Environmental Economics and Management, Vol. 37, pp. 165-182.

Yang, C.-H., Y.-H. Tseng and C.-P. Chen (2012), "Environmental regulations, induced R\&D, and productivity: Evidence from Taiwan's manufacturing industries", Resource and Energy Economics, Vol. 34, pp. 514-532.

Yörük, B. K. and O. Zaim (2005), "Productivity growth in OECD countries: A comparison with Malmquist indices", Journal of Comparative Economics, Vol. 33, pp. 401-420. 
ECO/WKP(2013)88

\section{WORKING PAPERS}

The full series of Economics Department Working Papers can be consulted at www.oecd.org/eco/workingpapers/

1095. Green growth challenges and the need for an energy reform in Mexico

(November 2013) by Carla Valdivia de Richter

1094. From bricks to brains: increasing the contribution of knowledge-based capital to growth in

Ireland

(November 2013) by David Haugh

1093. China's march to prosperity: reforms to avoid the middle-income trap

(November 2013) by Vincent Koen, Richard Herd and Sam Hill

1092. Multi factor productivity with natural capital

(November 2013) by Nicola Brandt, Paul Schreyer and Vera Zipperer

1091. Growth-promoting policies and macroeconomic stability (forthcoming)

(October 2013) by Douglas Sutherland and Peter Hoeller

1090. Policies for inclusive urbanisation in China

(October 2013) by Vincent Koen, Richard Herd, Xiao Wang and Thomas Chalaux

1089. Fiscal devaluation - can it help to boost competitiveness?

(October 2013) by Isabell Koske

1088. How to achieve growth- and equity-friendly fiscal consolidation? A proposed methodology for instrument choice with an illustrative application to OECD countries

(October 2013) by Boris Cournède, Antoine Goujard and Álvaro Pina

1087. Improving school-to-work transition in New Zealand

(September 2013) by Alexandra Bibbee

1086. The agri-food situation and policies in Switzerland

(September 2013) by Peter Jarrett and Charlotte Moeser

1085. Japan's challenging debt dynamics

(August 2013) by Yvan Guillemette and Jan Strasky

1084. Transitions in and out of unemployment among young people in the Irish recession

(August 2013) by Elish Kelly, Seamus McGuinness, Philip O'Connell, David Haugh and Alberto González Pandiella

1083. Is there convergence of Russia's regions? Exploring the empirical evidence: 1995-2010

(August 2013) by Hartmut Lehmann and Maria Giulia Silvagni

1082. The benefits and costs of highly expansionary monetary policy

(August 2013) by Lukasz Rawdanowicz, Romain Bouis and Shingo Watanabe

1081. The effectiveness of monetary policy since the onset of the financial crisis 
(August 2013) by Romain Bouis, Łukasz Rawdanowicz, Jean-Paul Renne, Shingo Watanabe and Ane Kathrine Christensen

1080. Responding to key well-being challenges in Austria

(August 2013) by Rauf Gönenç, Oliver Röhn, Christian Beer and Andreas Wörgötter

1079. Austria's well-being goes beyond GDP

(August 2013) by Oliver Röhn, Rauf Gönenç, Christian Beer and Romina Boarini

1078. Improving fiscal federal relations for a stronger Mexico

(August 2013) by Aida Caldera Sánchez

1077. Deleveraging: challenges, progress and policies

(August 2013) by Romain Bouis, Ane Kathrine Christensen and Boris Cournède

1076. Policies to support sustainable long-term growth in New Zealand

(July 2013) by Calista Cheung

1075. Do structural policies affect macroeconomic stability?

(July 2013) by Volker Ziemann

1074. A simple fiscal stress testing model - case studies of Austrian, Czech and German economies

(July 2013) by Ondra Kamenik, Zdenek Tuma, David Vavra and Zuzana Smidova

1073. Road connectivity and the border effect: evidence from Europe

(July 2013) by Henrik Braconier and Mauro Pisu

1072. Fiscal consolidation across government levels. Part 3: Intergovernmental grants, pro- or counter-cyclical?

(July 2013) by Hansjörg Blöchliger and Balázs Égert

1071. Fiscal consolidation across government levels. Part 2: Fiscal rules for sub-central governments, update of the institutional indicator

(July 2013) by Kaja Fredriksen

1070. Fiscal consolidation across government levels. Part 1: How much, what policies?

(July 2013) by Hansjörg Blöchliger

1069. Restructuring the electricity sector and promoting green growth in Japan

(June 2013) by Randall S. Jones and Myungkyoo Kim

1068. Labour market policies to promote growth and social cohesion in Korea

(June 2013) by Randall S. Jones and Satoshi Urasawa

1067. Education reform in Korea

(June 2013) by Randall S. Jones

1066. Belgium: enhancing the cost efficiency and flexibility of the health sector to adjust to population ageing

(June 2013) by Stéphane Sorbe 